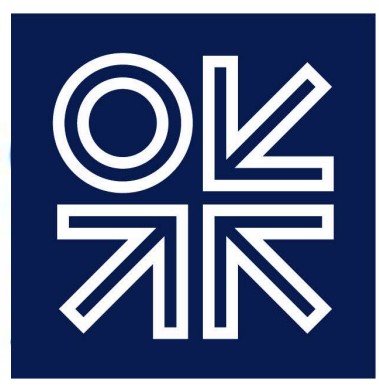

THE OXFORD INSTITUTE

FOR ENERGY STUDIES

August 2018

\title{
The Politics of Renewable Energy in East Africa
}

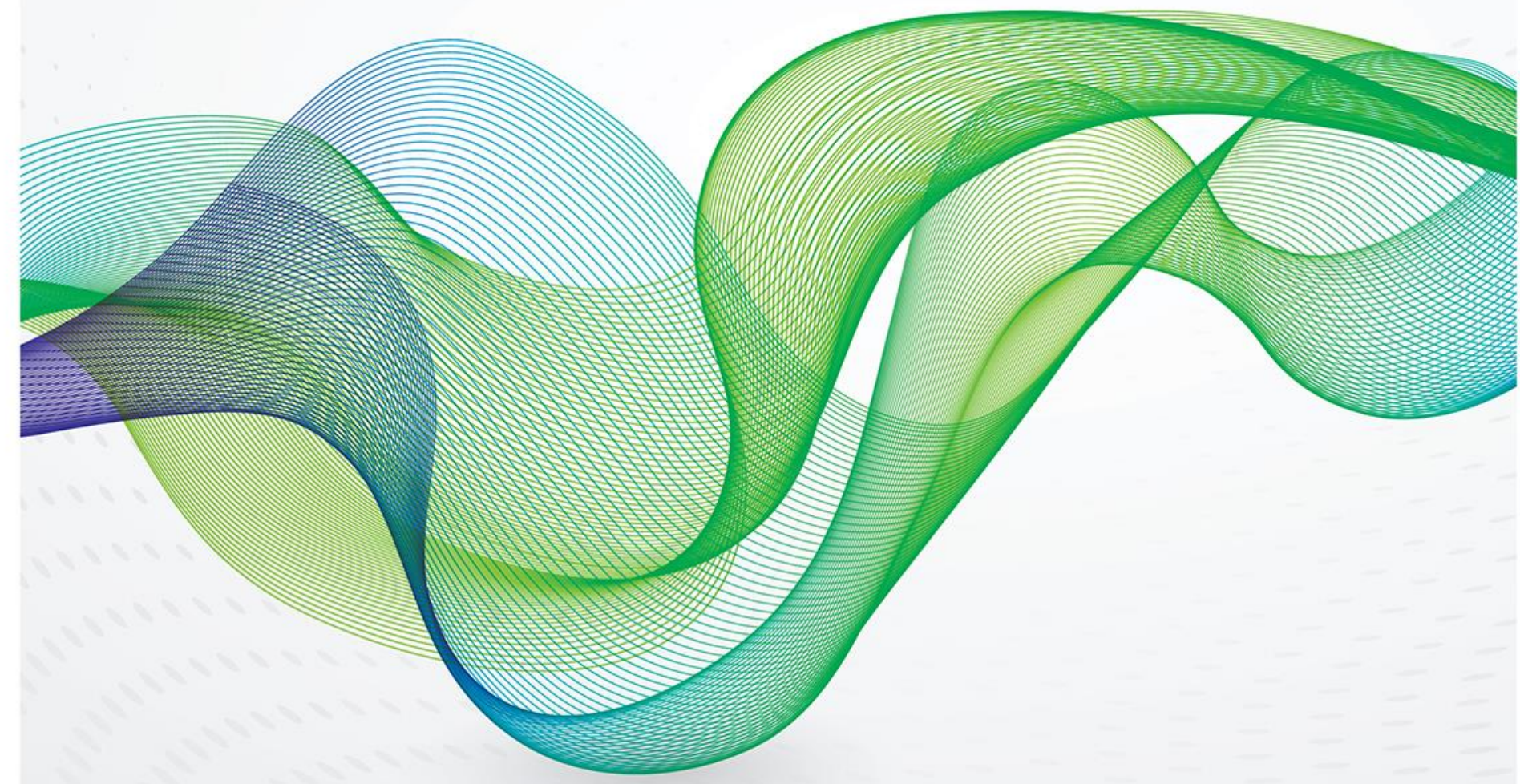



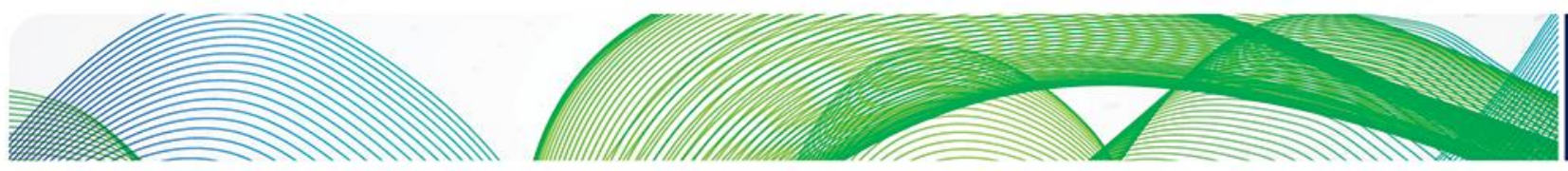

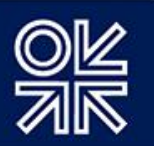

The contents of this paper are the author's sole responsibility. They do not necessarily represent the views of the Oxford Institute for Energy Studies or any of its members.

Copyright @ 2018

\section{Oxford Institute for Energy Studies}

(Registered Charity, No. 286084)

This publication may be reproduced in part for educational or non-profit purposes without special permission from the copyright holder, provided acknowledgment of the source is made. No use of this publication may be made for resale or for any other commercial purpose whatsoever without prior permission in writing from the Oxford Institute for Energy Studies.

ISBN 978-1-78467-118-1

DOI: https://doi.org/10.26889/9781784671181 

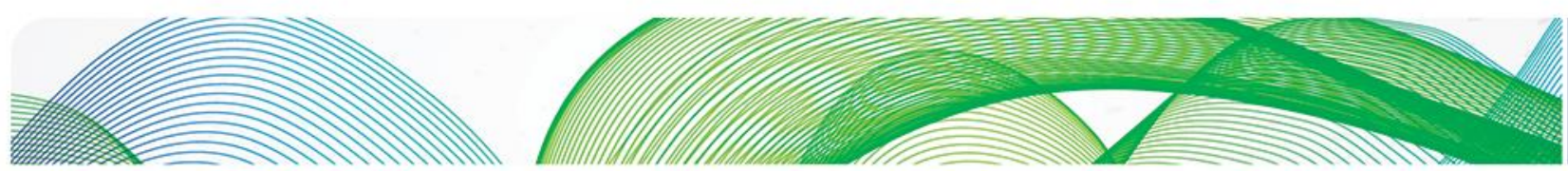
음

\section{Contents}

Contents. ii

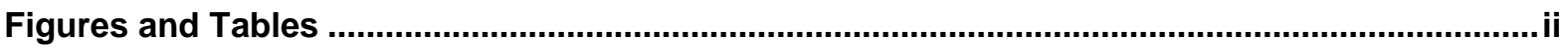

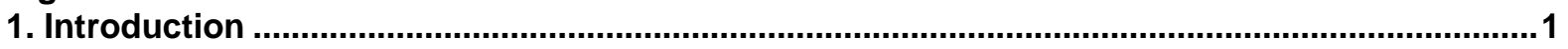

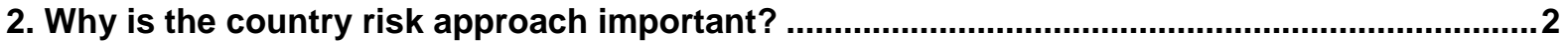

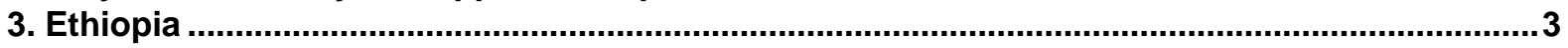

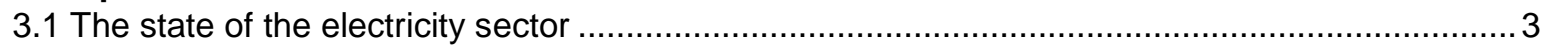

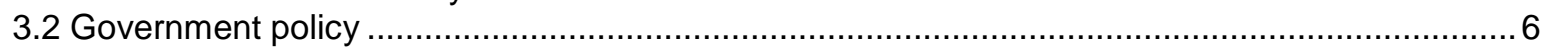

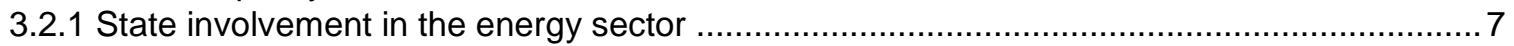

3.3 Regulatory environment and institutional reliability .......................................................... 7

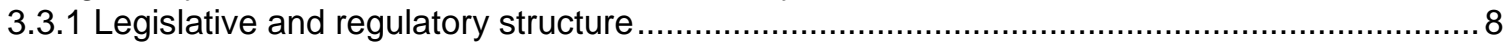

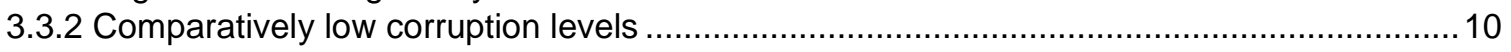

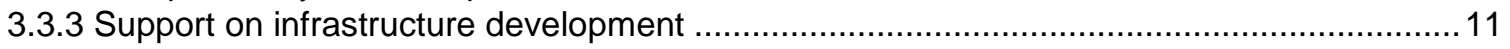

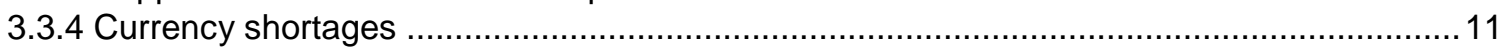

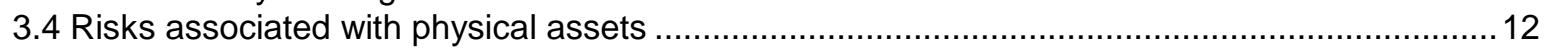

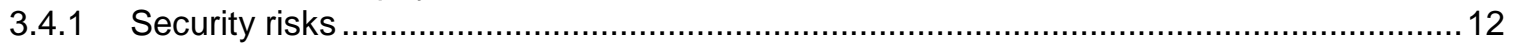

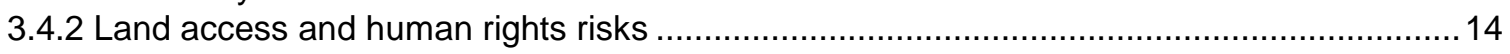

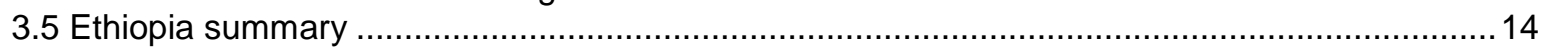

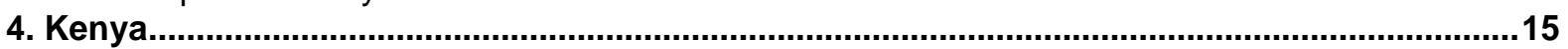

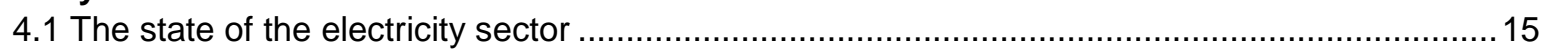

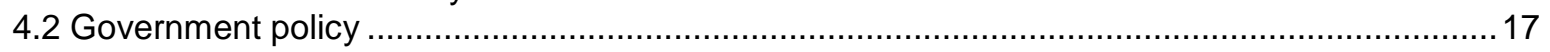

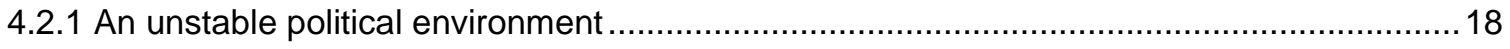

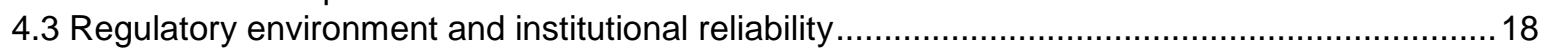

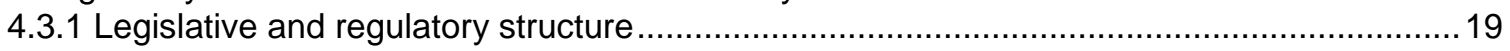

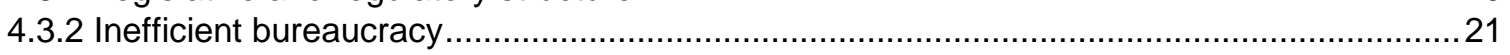

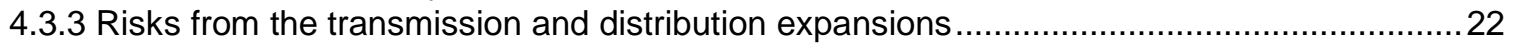

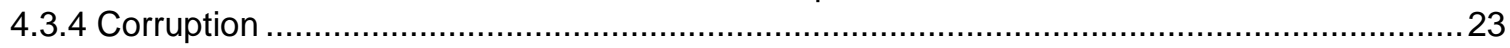

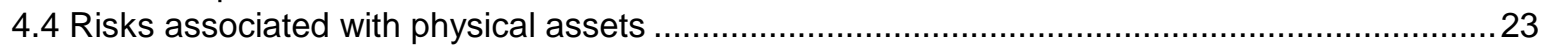

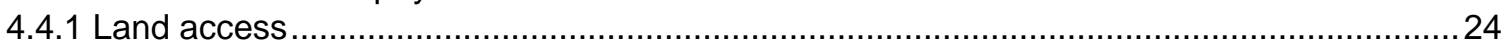

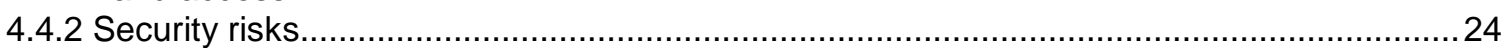

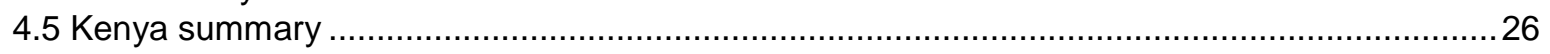

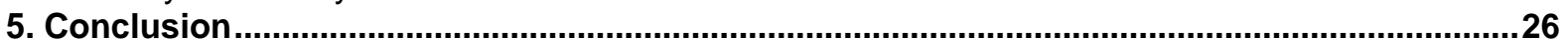

\section{Figures and Tables}

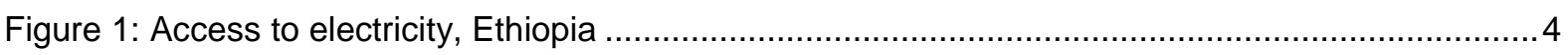

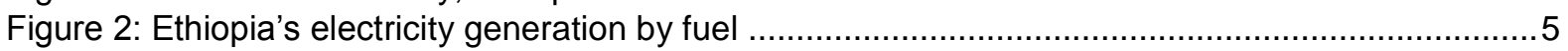

Figure 3: Renewable energy policies, Ethiopia .........................................................................

Figure 4: Violent incidents and fatalities in Ethiopia, January 2012 - May 2018..............................13

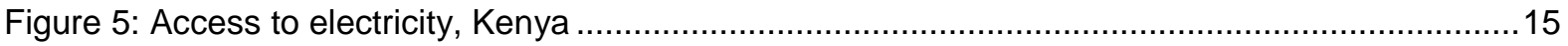

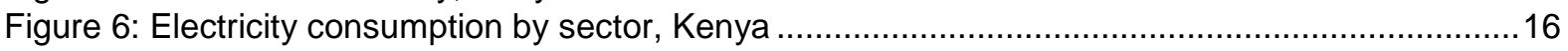

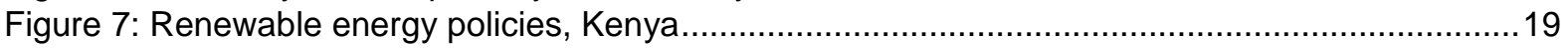

Figure 8: Violent incidents in Kenya, January 2012-May 2018 ..................................................25

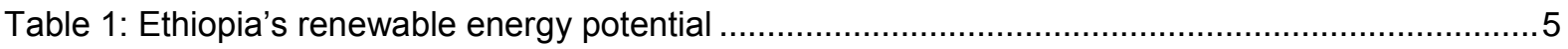

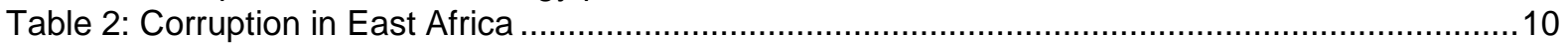

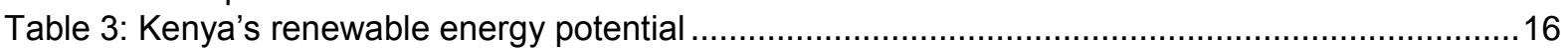

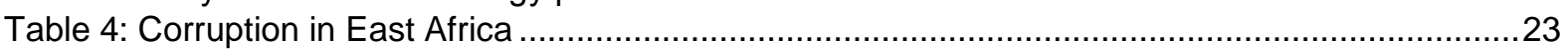



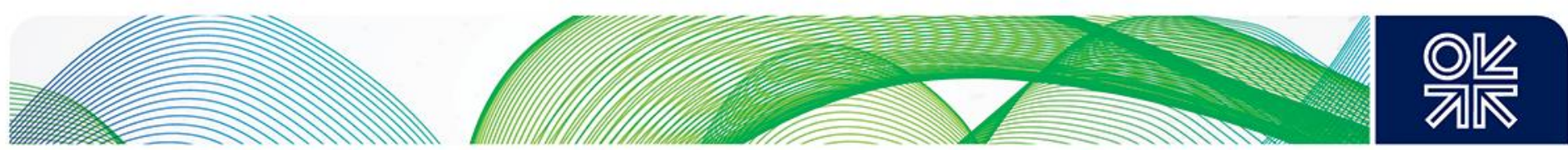

\section{Introduction}

Less than a quarter of East Africa's population has access to electricity - the lowest electrification rates in the world. This, combined with the region's vast natural resources, represent a major opportunity for renewable energy investors. Solar irradiation levels are high due to proximity to the equator, wind speeds are some of the strongest on the continent, hydropower resources are plentiful, and the Great Rift Valley is a promising source for geothermal power.

Until recently, renewable energy projects in sub-Saharan Africa were mostly limited to hydropower projects due to the prohibitively high generation costs of other power sources. Consumer electricity tariffs in the region are low, as are consumption levels outside of major urban areas, which has reduced the profit potential. However, as generation costs have plummeted the economics have shifted. Solar plants in southern Africa are estimated to pay for themselves within three years, and costs for utilityscale onshore wind and geothermal projects are now level with fossil fuel projects. This gives renewable energy companies an opportunity to gain a foothold in a market that is only expected to expand, due to rapid population growth and rising GDP levels.

This paper will compare the two largest economies in eastern Africa - Ethiopia and Kenya - to show how government policy impacts renewable energy investment. As the paper will discuss, such policies can have a significant effect on the regulatory, security, and political environments that investors encounter, resulting in a situation where some projects face a more favourable environment, while the financial viability of others is reduced. That said, investors also need to consider a range of other risks that are not directly discussed in this paper. These include risks associated with bringing technologies to areas where they have little or no track record, as well as counter-party risks of default or project curtailment.

As well as being two of the most developed economies in East Africa, Ethiopia and Kenya have a number of similarities when it comes to renewable energy. Both countries have ambitious renewables targets, while the presence of both baseload (in other words, continuous) and intermittent power sources mean that they are able to aim for 100 per cent renewable power sectors. However, they both lack comprehensive power infrastructure and have a history of failing to meet peak demand, leading to frequent power shortages. Both countries are therefore seeking to expand their off-grid systems, particularly in rural areas, and to improve their on-grid generation capacity.

The investment experience in Ethiopia and Kenya differs greatly. In Ethiopia the sector is only just opening up to private investment and the emphasis is on large, utility-scale projects. In Kenya, private companies have been present for decades and the country has become a hub for innovation in commercial off-grid and micro-grid systems.

These experiences reflect different political, regulatory, and security climates. In Ethiopia, the state dominates the economy and development is government driven. The power sector was, in practice, a state monopoly until 2017 , and although the government is committed to growing renewable capacity, its approach has stifled growth, particularly in off-grid systems. The government retains a preference for large on-grid projects that it can control. Increasingly, investors are likely to be granted generous incentives to enter the Ethiopian market and the government will support them with the necessary infrastructure development.

In Kenya, theoretically, the market drives economic and social development. As a result, the private sector has more freedom to operate. Consequently, Kenya has become a hub of innovation for off-grid solutions. In 2015, East Africa accounted for over half the global investment in off-grid systems, primarily in Kenya and Tanzania. Kenya's regulatory environment welcomes distributed energy systems, particularly in rural areas. Equally, from an investor's perspective, these projects reduce some of the biggest risks associated with foreign companies in Kenya - notably land access, security risks, and high levels of bureaucratic inefficiency and corruption. 

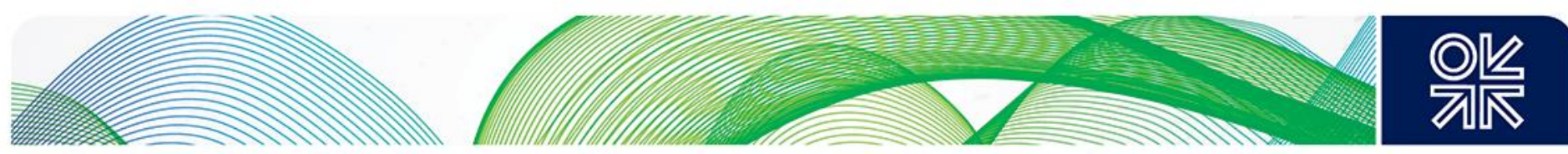

Multiple challenges faced by investors in each country can prevent projects from securing international financing. However, if investors seek to understand the drivers of risk, they will have a greater understanding of where to expect instability. This paper will therefore use a country risk approach to highlight the challenges and opportunities for investors in Ethiopia and Kenya. The case studies will focus on three core areas:

- Government policy: including the nature of the political system and the level of state involvement in the energy sector.

- Institutional reliability: including the legislative and regulatory environment for renewable energy, key players and legislation, incentives offered to renewables investors, and notable issues such as corruption and currency shortages.

- Risk to physical assets: including the changing security environment and land access risks as well as the related human rights risks associated with large construction projects.

Reviewing these three areas shows the comparatively low risk associated with on-grid projects in Ethiopia and off-grid projects in Kenya.

\section{Why is the country risk approach important?}

The first major obstacle for many renewable energy projects in Africa is securing international financing. Reaching a financial close can take over five years longer for African projects than for their counterparts in more stable investment environments. ${ }^{1}$ These delays are evident in the two largest on-grid developments covered in this report. The Lake Turkana Wind Power Project in Kenya took nine years to reach a financial close; the Corbetti geothermal project in Ethiopia has taken seven years, and financial close is still an estimated 18 months away. ${ }^{2}$

For many private investors, Africa presents an unfamiliar and potentially unstable operating environment. Given the limited sources of domestic financing, historically, the majority of infrastructure projects on the continent were financed by export credit agencies, multilateral institutions, or bilateral deals. This was primarily because project costs were too high for companies to fund themselves, and institutional investors were hampered by the region's bad credit history. Only 24 of the 49 countries on the continent have been assigned a credit rating by the three major ratings agencies, and of those only three are ascribed an investment-grade rating. ${ }^{3}$

Despite this, the appetite for renewable energy projects in Africa has increased over the last few years. The cost of solar and wind equipment has plummeted, and meanwhile several companies have demonstrated the commercial viability of off-grid and micro-grid solutions. In October 2017, M-Kopa (Kenya) raised a massive USD80 million in debt financing. Similarly, in January 2018, Off Grid Electric (Ghana, Tanzania, Rwanda, Burundi) raised USD55 million - the largest pure venture equity round for this type of company. ${ }^{4}$

\footnotetext{
${ }^{1}$ Ulrich Elmer Hansen, Mathilde Brix Pedersen, Ivan Nygaard (2015), 'Review of solar PV policies, interventions and diffusion in East Africa', Renewable and Sustainable Energy Reviews, Volume 46, pp.236-48: https://www.sciencedirect.com/science/article/pii/S1364032115001343?via\%3Dihub.

2 Bloomberg (2018a), 'Ethiopian Geothermal Is Private Equity’s Next \$4-Billion Bet', 5 February 2018: https://www.bloomberg.com/news/articles/2018-02-05/ethiopian-geothermal-is-private-equity-s-next-4-billion-bet (accessed 27 June 2018)

${ }^{3}$ The three countries with investment grade ratings are Botswana, Mauritius, and South Africa (although only Moody's assigns South Africa an investment grade rating).

${ }^{4}$ Greentech Media (2018), 'Off Grid Electric Secures \$55 Million in Series D Financing', 24 January 2018 : https://www.greentechmedia.com/articles/read/55-million-investment-sets-new-record-for-off-grid-servicecompanies\#gs.jg4GWK8 (accessed 27 June 2018); Renewables Now (2017b), 'Kenya's M-Kopa Solar raises USD 80m for
} 

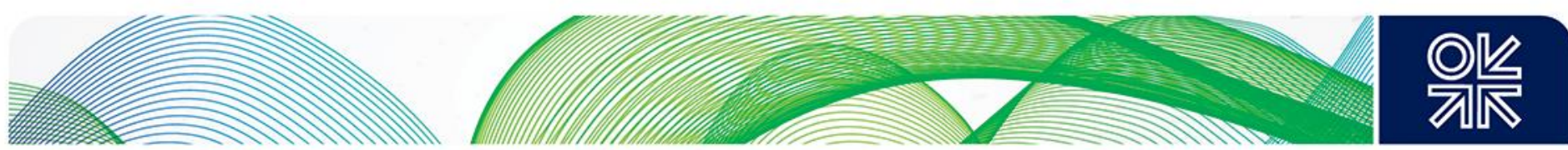

While this demonstrates that investors are willing to absorb the risk associated with investments in Africa, they do still have a significant number of expectations prior to financing. As one study on renewable financing described:

\begin{abstract}
'Project economics must be strong and debt repayment reasonably assured; all project risks must be identified, allocated and mitigated in a satisfactory manner; and all parties to the project (contractors, operators, off-takers) must be reliable, experienced and creditworthy. Finally, sponsors must demonstrate the fiscal and economic sustainability of any incentives allocated to renewables projects ... Smaller minigrid projects face the same uncertain credit environment and risk-averse lenders as larger renewable power stations in SSA [sub-Saharan Africa]. ${ }^{.5}$
\end{abstract}

Understanding the political, regulatory, and security environment is a vital part of the risk assessment process. Among other things it enables investors to establish whether they can expect a supportive policy environment, predictable tariffs, standardized contracts, and physical security for their assets. ${ }^{6}$ Each country presents a unique risk environment and knowing the drivers of these risks should be a fundamental part of the project financing process.

\title{
3. Ethiopia
}

Ethiopia's abundant natural resources, ambitious electrification targets, and green credentials make a seemingly perfect combination for investors in renewables. However, its state-dominated approach to economic development has limited private sector growth. Since 2017, the government has opened the energy market to international investors. It has become a willing partner, offering generous incentives and supporting investment with the rapid construction of relevant infrastructure. That said, it offers less support to off-grid projects, which sit less comfortably with Ethiopia's centralized development approach.

\subsection{The state of the electricity sector}

Ethiopia has the second-highest installed generation capacity in sub-Saharan Africa at $4.5 \mathrm{GW}$, and a relatively advanced infrastructure network. ${ }^{7}$ In 2018, the World Bank estimated that

'nearly $80 \%$ of the Ethiopian population [are] living within proximity of mediumvoltage transmission lines'. ${ }^{8}$

\footnotetext{
pay-as-you-go solar', 17 October 2017: https://renewablesnow.com/news/kenyas-m-kopa-solar-raises-usd-80m-for-pay-as-yougo-solar-587265/ (accessed 27 June 2018).

${ }^{5}$ Paolo Curiel, Roderic Hodges, Taylor DeJongh (2012), 'Rich in resources, lacking in capital', EMEA Finance, The Green Issue, June/July 2012: http://www.taylor-dejongh.com/wp-content/uploads/2012/07/Renewable-energy-in-Africa.pdf (accessed 27 June 2018).

${ }^{6}$ Amadou Sy and Amy Copley (2017), 'Closing the Financing Gap for African Energy Infrastructure: Trends, Challenges, and Opportunities', Policy Brief, Brookings Institute, April 2017: https://www.brookings.edu/wpcontent/uploads/2017/04/global 20170417 africa-energy-infrastructure.pdf (accessed 27 June 2018).

7 World Bank (2018), 'Ethiopia's Transformational Approach to Universal Electrification', 8 March 2018: http://www.worldbank.org/en/news/feature/2018/03/08/ethiopias-transformational-approach-to-universal-electrification (accessed 27 June 2018).

${ }^{8}$ World Bank (2018), 'Ethiopia's Transformational Approach to Universal Electrification', 8 March 2018: http://www.worldbank.org/en/news/feature/2018/03/08/ethiopias-transformational-approach-to-universal-electrification (accessed 27 June 2018).
} 

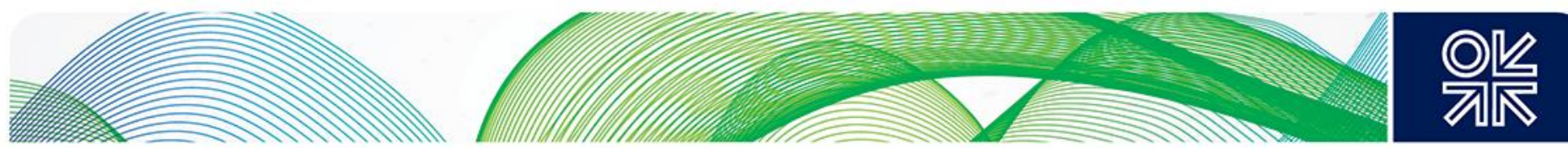

Despite this seemingly strong enabling environment only 43 per cent of the population, 24 per cent of primary schools, and 30 per cent of health clinics have access to electricity (see Figure 1). ${ }^{9}$

Figure 1: Access to electricity, Ethiopia

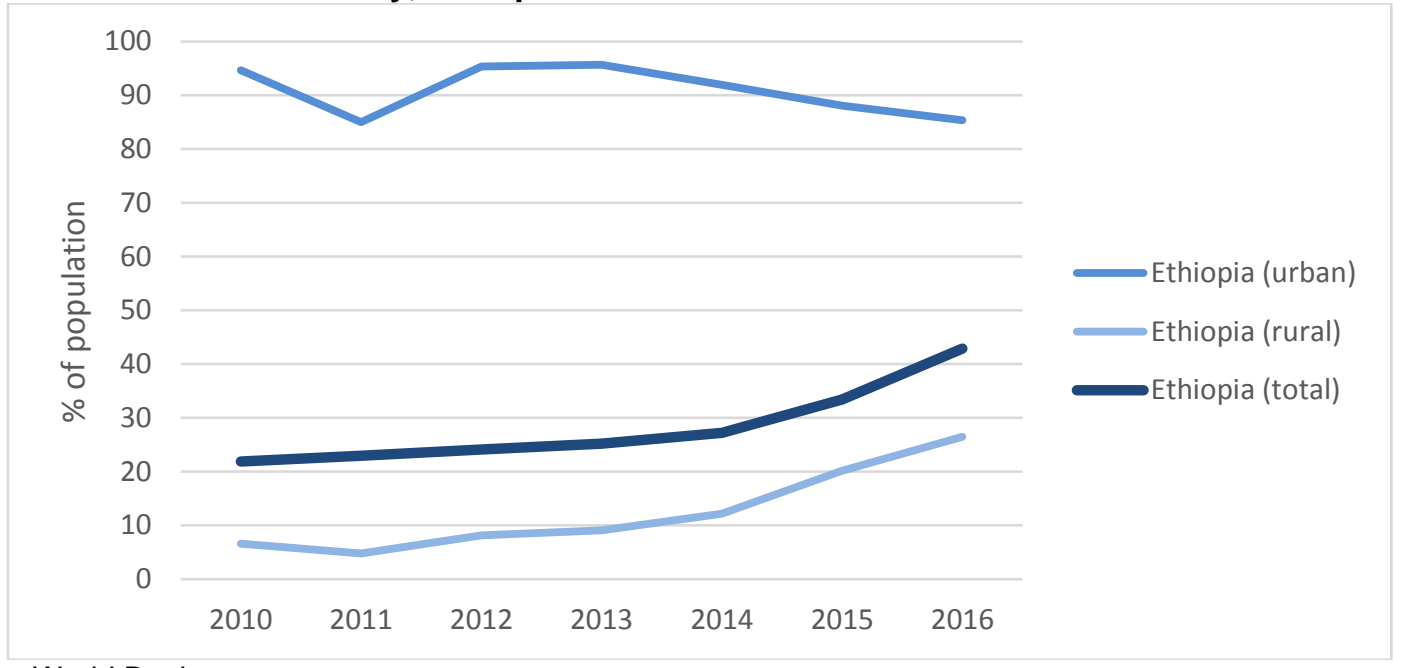

Source: World Bank.

This contradiction is a result of policy decisions which have focused on a centralized, top-down approach to electricity expansion. Development of the country's power sector is provided by the Growth and Transformation Plan (GTP) - the national development plan that dictates the majority of prominent government policies. ${ }^{10}$ The GTP was first released in 2010, by then-prime minister and founder of the current Ethiopian state, Meles Zenawi. It ran for five years, and was replaced by GTP II in 2016.

The primary objective of the GTP is that Ethiopia reach middle-income status by 2025 . Electricity generation and access are crucial to this goal. The first GTP called for a quadrupling of generation capacity from $2 \mathrm{GW}$ to $8 \mathrm{GW}$. Despite falling short of this target, ambition only grew, with GTP II setting a target of $17 \mathrm{GW}$ by 2020. Huge hydropower projects - notably the Grand Ethiopian Renaissance Dam (GERD) - as well as five new wind farms, aim to bring the country to $5 \mathrm{GW}$ by $2020 .{ }^{11}$

A remarkable result of these development plans is that Ethiopia's power sector is one of the very few worldwide to have an electric grid supplied almost exclusively by renewable energy. ${ }^{12}$ The idea of Green Growth is enshrined in the GTP and at the UN Conference on Climate Change in 2015 (COP21), the Ethiopian government pledged to cut emissions by an ambitious 64 per cent by $2030 .{ }^{13}$

\footnotetext{
${ }^{9}$ World Bank (undated-1), 'Access to electricity (\% of population)', undated: https://data.worldbank.org/indicator/EG.ELC.ACCS.ZS?locations=ET-KE\&name desc=false (accessed 27 June 2018); World Bank (2018), 'Ethiopia's Transformational Approach to Universal Electrification', 8 March 2018:

http://www.worldbank.org/en/news/feature/2018/03/08/ethiopias-transformational-approach-to-universal-electrification (accessed 27 June 2018).

${ }^{10}$ Growth and Transformation Plan II (GTP II), EuropeAid, International Cooperation and Development, European Commission, 2016: https://europa.eu/capacity4dev/resilience ethiopia/document/growth-and-transformation-plan-ii-gtp-ii-201516-201920.

${ }^{11}$ CNN (2017), 'Riders on the storm: Ethiopia bids to become wind capital of Africa', 3 January 2017: https://edition.cnn.com/2016/12/20/africa/ethiopia-wind-power/index.html (accessed 27 June 2018).

${ }_{12}$ Other countries with $100 \%$ renewable energy include Iceland and Costa Rica.

${ }^{13}$ Within the GTP, two policy plans cover the effort to create a green economy: the Nationally Appropriate Mitigation Actions (NAMA) and the Climate Resilient Green Economy plan (CRGE).

Addis Standard (2013), 'Is Ethiopia Ready To Make The Best Of Renewable Energy?', 3 December 2013:

http://addisstandard.com/as-of-yet-there-is-no-official-ppa-document-and-fit-proclamation-is-ethiopia-ready-to-make-the-bestof-renewable-energy/ (accessed 27 June 2018).
} 

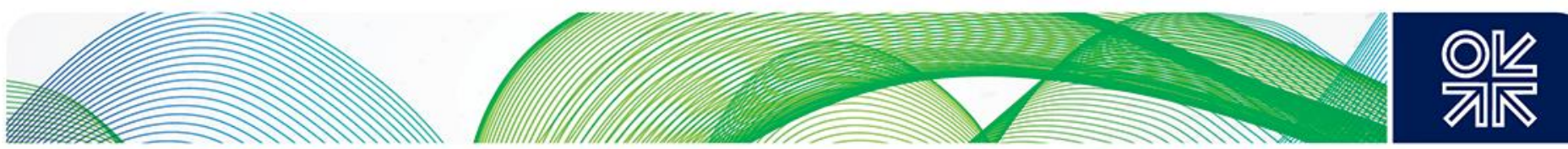

Such policy concerns preclude the development of fossil fuel-generated power. However, there is still an urgency for the government to diversify. It is currently overly dependent on hydropower, which will become less reliable as droughts intensify. ${ }^{14}$ Hydropower projects will remain the main source of baseload power, supplemented by new geothermal developments, but these will need to be supported by intermittent sources such as wind and solar to meet peak demand (see Figure 2).

Table 1: Ethiopia's renewable energy potential

\begin{tabular}{|l|c|c|l|}
\hline Power type & Target & Potential & Region \\
\hline Hydropower & $22 \mathrm{GW}$ by 2030 & $45 \mathrm{GW}$ & Nile basin, Abbay basin, Omo basin. \\
\hline Geothermal & $\begin{array}{c}450 \mathrm{MW} \text { by } 2018 \\
1 \mathrm{G} \mathrm{W} \text { by } 2030\end{array}$ & $\begin{array}{l}\text { Wind speeds between } 8 \mathrm{~m} / \mathrm{s} \text { and } 4 \mathrm{~m} / \mathrm{s}: \\
\text { Mekelle region, Nazareth, Gondar, Harar, } \\
\text { Debre Birhan, and Sululta. } \\
\text { Medium wind speeds in the eastern and } \\
\text { central Rift Valley. }\end{array}$ \\
\hline $\begin{array}{l}\text { Biopower from } \\
\text { bagasse }\end{array}$ & $103.5 \mathrm{MW}$ & Unclear & Garious \\
\hline
\end{tabular}

Source: EEP, 2016.

Figure 2: Ethiopia's electricity generation by fuel

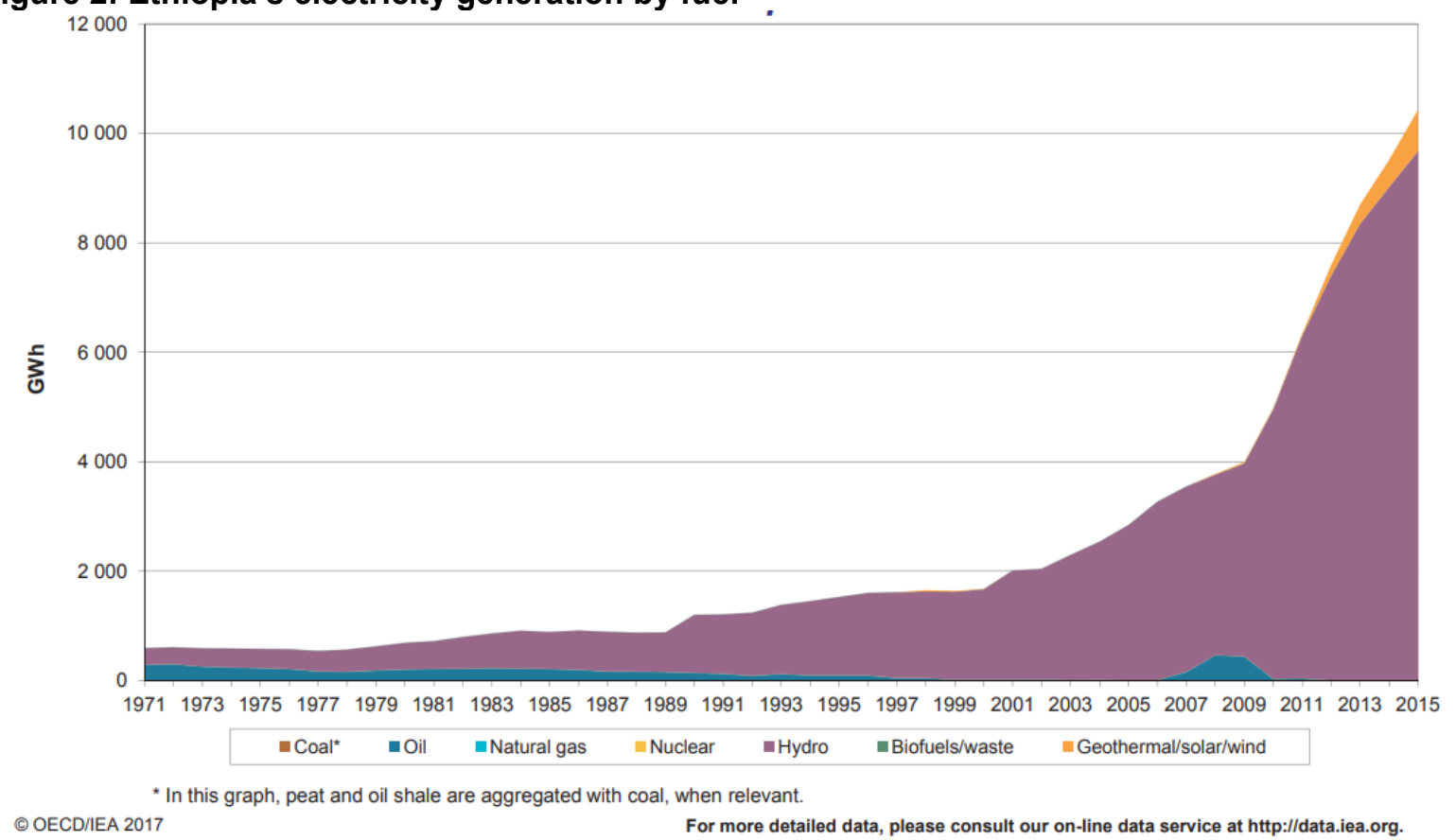

Source: IEA.

The COP21 pledge is significantly higher than pledges made by other countries in the region; Uganda committed to cut emissions by $22 \%$, Kenya by $30 \%$, and Djibouti by $40 \%$. CarbonBrief (2015), 'Paris 2015: Tracking country climate pledges', 16 September 2015: https://www.carbonbrief.org/paris-2015-tracking-country-climate-pledges (accessed 27 June 2018).

${ }^{14}$ Due to climate change, droughts in Ethiopia are becoming longer and more frequent, bringing significant risks of famine. In 2018, areas of the country, notably the Somali region, faced their fourth consecutive year of drought. Phys (2018), 'Worsening Ethiopian drought threatens to end nomadic lifestyle', PhysOrg, 13 February 2018: https://phys.org/news/2018-02-worseningethiopian-drought-threatens-nomadic.html (accessed 27 June 2018). 

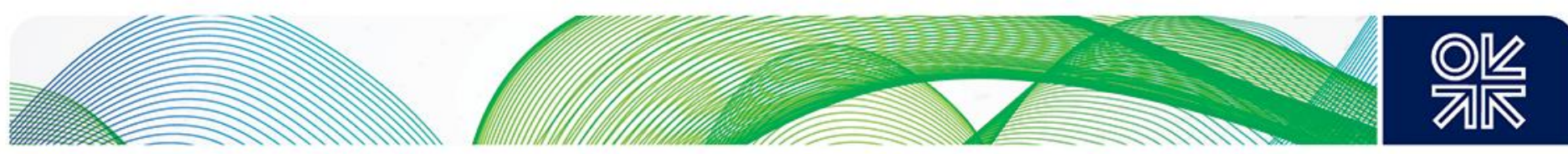

Although the government has acknowledgement that off-grid and micro-grid projects ${ }^{15}$ are important for rural electrification, the vast majority of power comes from large on-grid sources. For the coming five years, the emphasis on utility-scale projects is unlikely to waver since it follows the government's centralized model.

\subsection{Government policy}

Due to the centralized nature of the state, Ethiopia's politics, economy, and business spaces are closely intertwined. The country is often likened to China in that it adopts an economy-first development approach, with the idea that social development will follow growth. Given the dominance of the state, an understanding of the political system is vital for investors.

\section{Structure of the political system}

The Ethiopian state is tightly controlled by the ruling coalition, the Ethiopian People's Revolutionary Democratic Front (EPRDF). The EPRDF is made up of four constituent parties based on ethnic groups:

- The Tigrayan People's Liberation Front (TPLF),

- The Amhara National Democratic Movement (ANDM),

- The Oromo Peoples' Democratic Organization (OPDO),

- The Southern Ethiopian People's Democratic Movement (SEPDM).

Historically, the TPLF has dominated politics, the military, and the business environment, despite its ethnic group - the Tigray - making up less than 10 per cent of the population. In March 2018, this changed dramatically when Dr Abiy Ahmed, an Oromo, was appointed prime minister. Ahmed was appointed following the resignation of Hailemariam Desalegn in the wake of widespread antigovernment protests in Oromia and Amhara.

Ahmed's inauguration marked an important milestone for the country, and he is likely to introduce several reforms to liberalize both the political space and the economy. ${ }^{16} \mathrm{He}$ has already made significant changes to the Cabinet that reduce the power of the old guard. ${ }^{17}$ However, Tigrayan hawks still control the military and intelligence services, which they are likely to use to maintain political relevance. As a result, the state-dominated model and strict adherence to the GTP will remain in place for at least the next five years.

Ethiopia has seen double-digit growth for over a decade, almost entirely driven by public investment. ${ }^{18}$ A 2016 World Bank report underlined that while the country has the third-highest public investment rate in the world, it has the sixth-lowest private investment rate. ${ }^{19}$ The largest companies in the country are state-owned enterprises or those affiliated with the ruling party.

\footnotetext{
${ }^{15}$ Off-grid and micro-grid systems are forms of distributed energy. Off-grid refers to electricity projects that are not connected to the national grid and therefore do not rely on public utilities. Micro-grids, or mini-grids, are groups of interconnected energy assets. They are primarily off-grid, but can also be connected to the national grid.

${ }^{16}$ Africa Confidential (2018), 'All things to all factions', 1 June 2018: https://www.africa-confidential.com/articlepreview/id/12341/All things to all factions (accessed 27 June 2018).

${ }^{17}$ Africa Confidential (2018), 'All things to all factions', 1 June 2018: https://www.africa-confidential.com/articlepreview/id/12341/All things to all factions (accessed 27 June 2018).

${ }^{18}$ World Bank (undated-2), 'The World Bank in Ethiopia', undated: http://www.worldbank.org/en/country/ethiopia/overview (accessed 27 June 2018)

${ }^{19}$ World Bank (2016a), 'Ethiopia: Priorities for Ending Extreme Poverty and Promoting Shared Prosperity', 30 March 2016 : http://documents.worldbank.org/curated/en/913611468185379056/pdf/100592-REVISED-P154064-PUBLIC-Ethiopia-SCDMarch-30-2016-web.pdf (accessed 27 June 2018).
} 

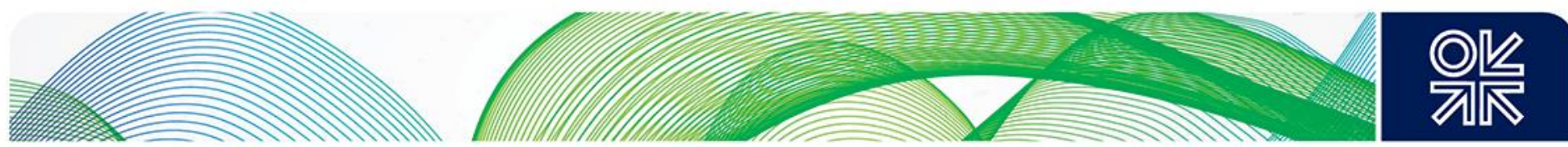

\subsubsection{State involvement in the energy sector}

Until recently the electricity sector was a state monopoly run by the Ethiopian Electric Power Corporation (EEPCo). ${ }^{20}$ Private involvement in the sector was limited to Engineering, Procurement, and Construction (EPC) contracts that were funded by concessional loans to the state. For example, in 2013, the $120 \mathrm{MW}$ Ashegoda wind farm was built by French-owned Vergnet and was funded by a EUR210 million concessional loan from the French development agency (AFD) and BNP Paribas. ${ }^{21}$ However, upon completion it was fully owned and operated by EEPCo.

The government has acknowledged the need to increase capital investment in the electricity sector. However, it would prefer to utilize public investment for infrastructure needs that cannot generate selfsustaining revenue. ${ }^{22}$ It has therefore committed to drawing in more international investors, and in 2017 the government signed its first Independent Power Production (IPP) contract with Corbetti Geothermal. ${ }^{23}$ This represents a major turning point. Further, in June 2018, the government announced that it was considering opening up Ethiopian Electric Power (EEP) ${ }^{24}$ to partial privatization. ${ }^{25}$ Despite these steps, the government maintains tight control over the sector and of the direction in which it develops.

\subsection{Regulatory environment and institutional reliability}

The regulatory regime in Ethiopia is relatively sparse. For example, the country does not yet have key policies such as a feed-in tariff or net metering - mechanisms that ensure the price at which producers can sell power back to the grid (see Figure 3). Where legislation is in place, the focus is heavily on large-scale, grid-integrated projects.

Figure 3: Renewable energy policies, Ethiopia

\begin{tabular}{|c|c|c|c|c|c|c|c|c|c|c|}
\hline \multirow[b]{2}{*}{ Country } & \multicolumn{2}{|c|}{ Targets } & \multicolumn{5}{|c|}{ Regulatory policies } & \multicolumn{3}{|c|}{ Fiscal incentives and public financing } \\
\hline & $\begin{array}{l}\text { Renewable } \\
\text { energy targets }\end{array}$ & $\begin{array}{l}\text { Renewable } \\
\text { energy in } \\
\text { INDC or NDC }\end{array}$ & $\begin{array}{l}\text { FiT/premium } \\
\text { payment }\end{array}$ & Net metering & $\begin{array}{l}\text { Transport } \\
\text { obligation/ } \\
\text { mandate }\end{array}$ & $\begin{array}{l}\text { Heat } \\
\text { obligation/ } \\
\text { mandate }\end{array}$ & Tendering & $\begin{array}{l}\text { Reductions in } \\
\text { sales, energy, } \\
\text { VAT or other } \\
\text { taxes }\end{array}$ & $\begin{array}{l}\text { Energy } \\
\text { production } \\
\text { payment }\end{array}$ & $\begin{array}{l}\text { Public } \\
\text { investment, } \\
\text { loans, grants, } \\
\text { capital } \\
\text { subsidies or } \\
\text { rebates }\end{array}$ \\
\hline Ethiopia & $\mathrm{x}$ & $\mathrm{x}$ & & & $\mathrm{x}$ & & & $\mathrm{x}$ & & $\mathrm{x}$ \\
\hline Kenya & $\mathrm{x}$ & $\mathrm{x}$ & $\mathrm{x}$ & $\mathrm{x}$ & & $\mathrm{x}$ & (Historical) & $\mathrm{x}$ & $\mathrm{x}$ & $\mathrm{x}$ \\
\hline
\end{tabular}

Source: IRENA, 2017.

\footnotetext{
${ }^{20}$ The only exception was off-grid transmission and supply, which was opened to private investors in 2003. Federal Negarit Gazeta (2003) Investment (Amendment) Proclamation No 373/2003, Federal Democratic Republic of Ethiopia: http://ethiopianchamber.com/Data/Sites/1/downloadables/INVESTMENT\%20\%20CODE/INVESTMENT\%20PROCLAMATION \%20-\%20AMMENDMENT\%20-\%20NUMBER\%20375-1996.pdf. Liilnna Kifle (2018), 'The legal basis for Power Purchase Agreements in Ethiopia', Mehrteab Leul \& Associates, 24 January 2018: https://www.mehrteableul.com/resource/blog/item/27the-legal-basis-for-power-purchase-agreements-in-ethiopia.html (accessed 27 June 2018).

${ }^{21}$ Power Technology (2013), 'EEPCO begins operations of 120MW Ashegoda wind farm in Ethiopia', 27 October 2013: https://www.power-technology.com/uncategorised/newseepco-begins-operations-of-120mw-ashegoda-wind-farm-in-ethiopia/ (accessed 27 June 2018).

${ }^{22}$ Getting the deal through (2017a), 'Renewable Energy: Ethiopia', Law Business Research Ltd., October 2017: https://gettingthedealthrough.com/area/99/jurisdiction/219/renewable-energy-2018-ethiopia/ (accessed 27 June 2018).

${ }^{23}$ The Corbetti Geothermal Project will add $20 \mathrm{MW}$ to the grid, and the government hopes it will kick-start investment in geothermal energy in the country.

${ }^{24}$ EEPCo was split into Ethiopian Electric Power (EPP) and Ethiopian Electric Utility (EEU) in 2013 as part of a sector restructuring process designed to increase efficiencies.

${ }^{25}$ Cross-border Information (2018), 'Ethiopia: EEP privatisation among mooted reform', 14 June 2018:

https://archive.crossborderinformation.com/Article/Ethiopia+EEP+privatisation+among+mooted+reforms.aspx?date=20180614\# (accessed 27 June 2018); Reuters (2018c), 'Ethiopia loosens throttle on many key sectors, but privatization still far off', 6 June 2018: https://www.reuters.com/article/us-ethiopia-privatisation/ethiopia-loosens-throttle-on-many-key-sectors-but-privatizationstill-far-off-idUSKCN1J21QV (accessed 27 June 2018).
} 

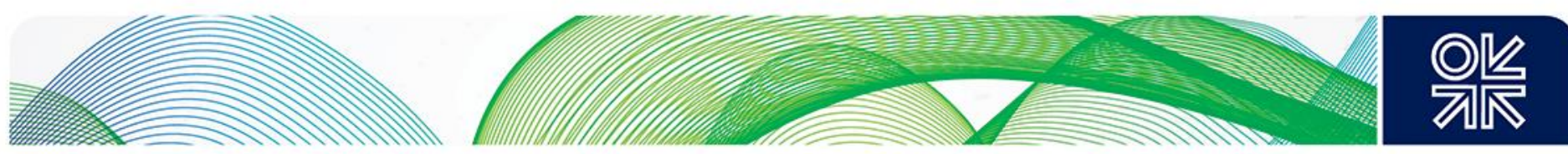

Regulation gaps undermine the ability of investors to attract financing - which tends to require such policies in order to guarantee stability and profit predictability. As of 2017,128 countries worldwide have national power policies which extend to feed-in tariffs or net metering. Ethiopia will be uncompetitive if it cannot keep up with market norms. ${ }^{26}$

However, the government has proved to be a willing partner by offering generous incentives and expedited access to decision makers. Renewable energy investors are therefore likely to find fewer bureaucratic hurdles than in neighbouring Kenya. That said, the environment for off-grid investors is far less developed, and all companies will need to contend with the ongoing currency shortages.

\subsubsection{Legislative and regulatory structure}

To operate in the country, investors will need to deal with the following state bodies:

- Ministry of Water, Irrigation and Electricity ${ }^{27}$ The Ministry oversees the sector and sets energy policy. Its Procurement Committee sets the guidelines for awarding EPC contracts and licences. The Ministry also sets the electricity tariff at grid level.

- Ethiopian Energy Authority (EEA) ${ }^{28}$ The EEA was created as a regulator in 2003. It is responsible for issuing investment permits and licences for generation, transmission, and distribution. It also approves plans for the import or export of energy. The EEA sets the tariff for off-takes from the grid. Renewable energy investors can apply for investment licences for 25 years for hydropower and geothermal, and 20 years for wind, solar, biomass, and energy from waste technologies. ${ }^{29}$

- Ethiopian Electric Power (EEP) ${ }^{30}$ EEP is responsible for generation and transmission. Private operators will need to partner with the EEP via a Power Purchase Agreement.

- Ethiopian Electric Utility (EEU) EEU is responsible for the distribution network. It purchases power from EEP, and can still be an off-taker for Independent Power Producers (IPPs).

Given that private investment in the electricity sector is a relatively new phenomenon in Ethiopia, regulation is still in its infancy. Over the last five years, the government has reformed and introduced new legislation for the sector, to drive up capital investment. Key legislation includes:

- Geothermal Resources Development Proclamation No. 981/2016:31 Sets out a framework for how geothermal resources are to be developed. Prior to this, geothermal power was covered by the 1998 Mining Law. Further geothermal regulations are slated for late $2018 .{ }^{32}$

- Energy Proclamation No. 810/2013:33 Provides for all renewable energy generation projects, including off-grid generation. In December 2017, an amendment was proposed that will extend the period between licensing and the date by which projects are required to be operational. (This period

\footnotetext{
${ }^{26}$ REN21 (2018), 'Chapter 2: Policy Landscape', Global Status Report, 2018: http://www.ren21.net/gsr2018/chapters/chapter 02/chapter 02/ (accessed 27 June 2018).

${ }^{27}$ Ministry of Water, Irrigation and Electricity, (2018), 'Home', undated: http://www.mowie.gov.et/et (accessed 27 June 2018).

${ }^{28}$ Power Africa (2015), 'Investment Brief for the Energy Sector in Ethiopia',

https://www.usaid.gov/sites/default/files/documents/1860/Ethiopia_IG_2015_05_03.pdf (accessed 10 August 2018).

${ }^{29}$ Norton Rose Fulbright (2016), 'Investing in the Ethiopia electricity sector: Ten things to know', 1 June 2016 :

https:/www.insideafricalaw.com/publications/ethiopia-investing-in-the-african-electricity-sector-ten-things-to-know (accessed 27

June 2018).

${ }^{30}$ Ethiopian Electric Power (2018), 'Home', undated: http://www.eep.gov.et/ (accessed 27 June 2018).

${ }^{31}$ Geothermal Resources Development Proclamation No. 981/2016:

http://www.ilo.org/dyn/natlex/natlex4.detail?p lang=en\&p isn=103970\&p count=2\&p classification=22

32 Getting the deal through (2017a), 'Renewable Energy: Ethiopia', Law Business Research Ltd., October 2017:

https://gettingthedealthrough.com/area/99/jurisdiction/219/renewable-energy-2018-ethiopia/ (accessed 27 June 2018).

${ }^{33}$ Federal Negarit Gazeta (2014), Proclamation No.810/2013, Federal Democratic Republic of Ethiopia:

https://chilot.files.wordpress.com/2014/09/proclamation-no-810-2013-energy-proclamation.pdf.
} 

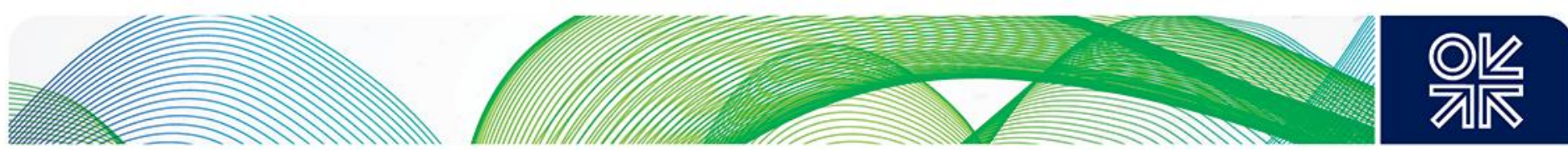

was previously twelve months but will be extended to a period of between three and five years. ${ }^{34}$ ) The amendment is highly likely to pass in 2018.

- Public-Private Partnership Proclamation No. 1076/2018:35 This applies beyond the energy sector, to major infrastructure and other public sector projects. This proclamation aims to facilitate private investment into major infrastructure works, including the power sector. ${ }^{36}$

Renewable energy - both on- and off-grid - is considered one of the so-called 'priority sectors' in that it is considered vital to the GTP. As such, investors are offered generous incentives including:

- Access to investment board: Chaired by the prime minister, the investment board sits quarterly for priority sectors to authorize investment licences. For non-priority sectors, it can take up to a year to get access to the board. ${ }^{37}$

- Access to currency: Ethiopia has experienced major foreign currency shortages over the last few years (see below). Priority sector investors face shorter delays - of up to three months compared with between six and nine months - to access hard currency. ${ }^{38}$

- Tax breaks: Renewable energy investors will be offered generous tax breaks that vary depending on the region they are operating in. These include tax holidays of between five and seven years, and exemptions on import tax. Projects in peripheral regions will be granted more generous incentives. ${ }^{39}$

- Expedited decision making: Priority sectors have greater access to decision makers, and are therefore likely to experience more efficient bureaucratic processes. This includes access to the one-stop shops of the Ethiopian Investment Authority across the country, where numerous federal agencies and service providers (such as banks and the national telecoms company) are housed under one roof. ${ }^{40}$

As an important draw for investors, the government is highly unlikely to remove these incentives because they reduce delays in the investment process by allowing for quicker decision making, while also reducing the number of bureaucratic processes.

\section{Gaps in the regulations}

Despite this progress, there are still numerous regulations that remain outstanding. The EEA is in the process of developing model Power Purchase Agreements and Implementation Agreements for all renewable technologies. This will remove a significant amount of uncertainty for future on-grid investors. These agreements will cement important protections for investors, notably a generation payment guarantee in the event of EEP defaulting ${ }^{41}$ Alongside these standardized agreements, the EEA has

\footnotetext{
${ }^{34}$ Addis Fortune (2017), 'Ethiopia: Energy Proclamation Amendment to Encourage Investment', 16 December 2017 : http://allafrica.com/stories/201712190902.html (accessed 27 June 2018).

${ }^{35}$ Ethiopian Legal Brief (2018), 'A Proclamation to provide for the Public Private Partnership', undated: https://chilot.me/wpcontent/uploads/2017/12/A-Proclamation-to-provide-for-the-Public-Private-Partnership.pdf (accessed 27 June 2018).

${ }^{36}$ Gowling WLG (20118), 'Ethiopia: Ethiopia Introduces A Public Private Partnership Law', 27 March 2018 : http://www.mondaq.com/x/686868/Government+Contracts+Procurement+PPP/Ethiopia+introduces+a+Public+Private+Partners hip+Law (accessed 27 June 2018).

${ }^{37}$ Anonymous employee at foreign diplomatic office in Addis, personal communication, February 2017.

${ }^{38}$ Anonymous employee at foreign diplomatic office in Addis, personal communication, February 2017.

${ }^{39}$ Anonymous local journalist, Addis, personal communication, February 2017.

${ }^{40}$ Capital Ethiopia (2013), 'Investment Agency strengthens its one-stop shop service', 22 July 2013:

http://capitalethiopia.com/2013/07/22/investment-agency-strengthens-its-one-stop-shop-service/ (accessed 27 June 2018 ).

${ }^{41}$ Liilnna Kifle (2018), 'The legal basis for Power Purchase Agreements in Ethiopia', Mehrteab Leul \& Associates, 24 January 2018: https://www.mehrteableul.com/resource/blog/item/27-the-legal-basis-for-power-purchase-agreements-in-ethiopia.html (accessed 27 June 2018).
} 

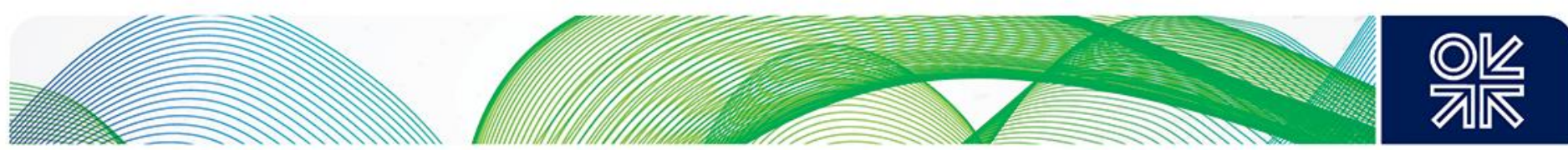

proposed introducing feed-in tariffs that would vary according to project size and technology. ${ }^{42} \mathrm{~A}$ standardized feed-in tariff regime would reduce the need for complex bilateral negotiations for each project, and hence would likely facilitate smooth project planning, as well as allowing for more certainty while seeking access to finance.

For off-grid and micro-grid companies, there is even more regulatory confusion, particularly over licencing and in the relationship of the companies with the rural electrification agencies. Private investment was authorized in 2013, but private sector involvement has not grown significantly beyond the sale of solar home systems. ${ }^{43}$ The government has sought to maintain a level of control of the offgrid developments and, with support from the World Bank or other development institutions, runs most of the solar home system expansion projects. ${ }^{44}$

Equally, there needs to be further harmonization of rural electrification agencies. Off-grid and microgrid projects often need to coordinate closely with these agencies, since they are likely to be serving the same market. In Ethiopia, there are six agencies involved in rural electrification and these have overlapping, and occasionally contradictory, policies. ${ }^{45} \mathrm{It}$ is therefore incredibly challenging for microand off-grid investors to establish whether or not they will find themselves competing with the government for customers, should rural electrification plans expand to cover their area of operation.

\subsubsection{Comparatively low corruption levels}

One of the noticeable advantages of Ethiopia is that is has lower corruption risks than all of its neighbours (see below and Table 2).

\section{Table 2: Corruption in East Africa}

\begin{tabular}{|l|l|l|l|}
\hline Country & Score & Rank & $\begin{array}{l}\text { Rank in sub-Saharan } \\
\text { Africa }\end{array}$ \\
\hline Ethiopia & 35 & 107 & $\mathbf{1 8}$ \\
\hline Kenya & 28 & 143 & 28 \\
\hline Uganda & 26 & 151 & 33 \\
\hline
\end{tabular}

Source: Transparency International, 2017.

Most businesses do not report the same level of bribery demands and corrupt tendering as in Kenya, Tanzania, or Uganda. However, as reported by the World Bank in 2012, the high level of government involvement creates

'a widespread perception of hidden barriers to market entry [as well as] an impression of favouritism.'46

\footnotetext{
${ }^{42}$ Norton Rose Fulbright (2016), 'Investing in the Ethiopia electricity sector: Ten things to know', 1 June 2016: https://www.insideafricalaw.com/publications/ethiopia-investing-in-the-african-electricity-sector-ten-things-to-know (accessed 27 June 2018).

${ }^{43}$ SE4All (2017), 'Mini Grid Market Opportunity Assessment: Ethiopia', Green Mini Grid Market Development Programme,

SEforALL, Africa Hub African Development Bank, April 2017: http://greenminigrid.se4all-africa.org/file/167/download (accessed 27 June 2018).

${ }^{44}$ ODI (2016), 'Accelerating access to electricity in Africa with off-grid solar: Off-grid solar country briefing: Ethiopia', Country Study, January 2016: https://www.odi.org/sites/odi.org.uk/files/odi-assets/publications-opinion-files/10247.pdf (accessed 27 June 2018); World Bank (2016b), 'Off-Grid Solar Lighting Up Ethiopia', 15 August 2016: http://www.worldbank.org/en/news/feature/2016/08/15/off-grid-solar-lighting-up-ethiopia (accessed 27 June 2018).

45 ODI (2016), 'Accelerating access to electricity in Africa with off-grid solar: Off-grid solar country briefing: Ethiopia', Country Study, January 2016: https://www.odi.org/sites/odi.org.uk/files/odi-assets/publications-opinion-files/10247.pdf (accessed 27 June 2018).

${ }^{46}$ Janelle Plummer (2012), Diagnosing Corruption in Ethiopia: Perceptions, Realities, and the Way Forward for Key Sectors. Directions in Development - Public Sector Governance, Washington DC: World Bank.
} 

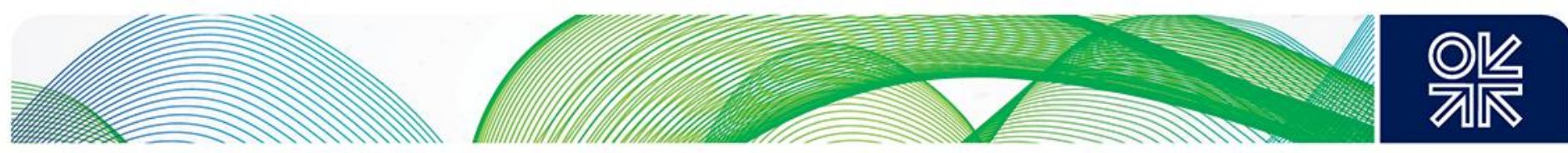

State-owned companies or those affiliated with the ruling parties are likely to be given special treatment, and investors will be expected to partner with them wherever possible ${ }^{47}$ Other than this, demands for bribes can be controlled through professionally managed systems including well-enforced codes of conduct, strong financial record keeping, and whistleblowing policies. ${ }^{48}$

\subsubsection{Support on infrastructure development}

The government has a track record for completing infrastructure projects without the repeated delays or cost inflations seen across the region. This is most evident in the transport sector, but is also true of the various hydropower projects that have come online in recent years. Much of this efficiency is due to the government's partnership with China, who provide the finance, equipment, and, frequently, the workforce for these projects. As with other 'priority sectors', the government supports China's contributions with tax breaks, quick decision-making, and land access.

This track record will comfort utility-scale renewables investors who are reliant on the expansion of transmission networks to get their electricity to market. As part of the National Electrification Program, the government plans to build 114 new transmission substations and $13,540 \mathrm{~km}$ of new $500 \mathrm{kV}$ to $66 \mathrm{kV}$ transmission lines by 2020.49 This will mark a dramatic increase from the $10,869 \mathrm{~km}$ of transmission lines in place in 2015.50

A further boost for would-be investors are the government's ambitious power export plans and its commitment to improving regional interconnectivity. Ethiopia is part of the East African Power Pool, and is either already delivering or en route to delivering power to Kenya, Tanzania, Rwanda, Sudan, and Djibouti. ${ }^{51}$ This significantly expands the potential market for on-grid projects.

\subsubsection{Currency shortages}

One of the most significant risks to companies operating in Ethiopia is currency shortages. Access to forex has been a major obstacle for businesses for years and this worsened over 2017 and 2018. ${ }^{52}$ Even in the 'priority sectors', which are given preferential access, businesses frequently complain about delays of over three months in accessing currency. ${ }^{53}$

The delays are the result of a systemic imbalance in the Ethiopian economy, which means that the government spends significantly more forex than it earns. The government's public investment programme requires numerous costly imports of machinery and equipment. While this programme is designed to promote the manufacturing sector - which is vital for increasing the country's exports - that sector still accounts for less than 10 per cent of the country's GDP. The resulting unfavourable trade balance is unlikely to reverse in the immediate future, meaning there will still be severe shortages of forex.

\footnotetext{
${ }^{47}$ In addition to the dominant state-owned enterprises, each of the constituent parties of EPRDF has its own endowment fund, the largest of which is EFFORT, the TPLF's fund. EFFORT owns companies in construction and transportation, and dominates the country's private logistics sector.

${ }^{48}$ Janelle Plummer (2012), Diagnosing Corruption in Ethiopia: Perceptions, Realities, and the Way Forward for Key Sectors. Directions in Development - Public Sector Governance, Washington DC: World Bank.

${ }^{49}$ Norton Rose Fulbright (2016), 'Investing in the Ethiopia electricity sector: Ten things to know', 1 June 2016: https://www.insideafricalaw.com/publications/ethiopia-investing-in-the-african-electricity-sector-ten-things-to-know (accessed 27 June 2018).

${ }^{50}$ Norton Rose Fulbright (2016), 'Investing in the Ethiopia electricity sector: Ten things to know', 1 June 2016: https://www.insideafricalaw.com/publications/ethiopia-investing-in-the-african-electricity-sector-ten-things-to-know (accessed 27 June 2018).

${ }^{51}$ The Eastern Africa Power Pool (undated), 'Home', undated: http://eappool.org/ (accessed 27 June 2018).

52 Capital Ethiopia (2018), 'Hard Times for Hard Currency', 2 April 2018: http://capitalethiopia.com/2018/04/02/hard-times-hardcurrency/\#.WzN4TNIzZhE (accessed 27 June 2018).

${ }^{53}$ Anonymous employee at foreign diplomatic office in Addis, personal communication, February 2017.
} 

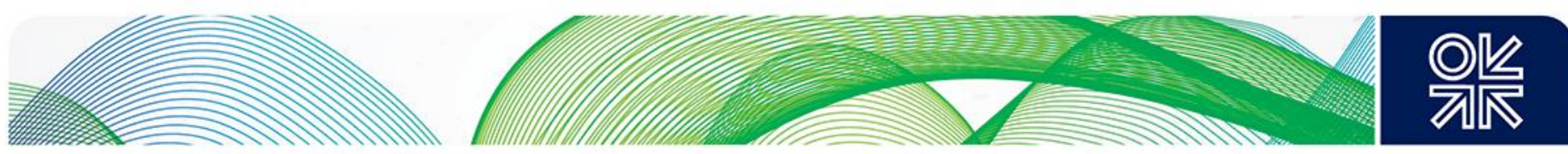

Despite this, the government has ploughed ahead with public spending, arguing that it is necessary to attract foreign investment, which in turn will relieve the forex shortage. In October 2017, the Central Bank devalued the currency in a bid to protect reserves, but this has had minimal effect. Since coming to power, Prime Minister Ahmed has shown more willingness to address the root causes of the shortages. While he has shown no inclination to reduce public spending, he has proposed the sale of stakes in EEP, along with the highly profitable state-owned Ethiopian Airlines and EthioTelecom (both monopolies). While this is likely to prove beneficial in the long run, Ahmed himself stated in April 2018 that the currency shortages might continue for 15 to 20 years. ${ }^{54}$

\subsection{Risks associated with physical assets}

Renewable energy investors need to manage the risk exposure of their physical assets. These risks are significantly higher for large utility-scale assets, since off-grid and micro-grid projects are by their nature small and dispersed.

Ethiopia has lower asset risks than many countries in the region. All land is government owned, removing access challenges. Ethiopia also presents a relatively stable security environment despite the recent uptick in protests. However, all companies operating in the country need to be aware of potential risks associated with human rights grievances, particularly in relation to land and labour issues (see below).

\subsubsection{Security risks}

Ethiopia has historically been considered a stable outlier in an unstable region. 55 Although numerous non-state armed groups do exist, their capacity is severely limited, in part due to the strength of the country's security forces.56 The most active groups are:

- the Ogaden National Liberation Front (ONLF) in the south-eastern Somali region of Ethiopia, and

- the Afar Revolutionary Democratic Unity Front (ARDUF) in the area bordering Eritrea.

Both groups have attacked foreigners in the past, and have threatened foreign business assets. ${ }^{57}$ Most notably, in 2007, the ONLF killed 74 people at a Chinese-run oilfield in Somali region. ${ }^{58}$

\footnotetext{
${ }^{54}$ Reuters (2018b), 'Ethiopian foreign exchange shortage will last years - new premier', 16 April 2018: https://www.reuters.com/article/ethiopia-economy/update-2-ethiopian-foreign-exchange-shortage-will-last-years-new-premieridUSL8N1RT61K (accessed 27 June 2018).

${ }^{55}$ The UK Department for International Trade describes the country as 'a relative "island of stability" in the volatile Horn of Africa.' Department for International Trade (2018), 'Overseas Business Risk - Ethiopia', 15 May 2018: https://www.gov.uk/government/publications/overseas-business-risk-ethiopia/overseas-business-risk-ethiopia (accessed 27 June 2018). Similarly, a report from the Brookings Institute in 2016 stated '[i]n a region where sectarian and ethnic tensions have a tendency to flare up, Ethiopia has achieved remarkable social cohesion.' Brookings Institute (2016), 'Ethiopia's outsized importance to African security', 29 April 2016: https://www.brookings.edu/blog/order-from-chaos/2016/04/29/ethiopias-outsizedimportance-to-african-security/ (accessed 27 June 2018).

${ }^{56}$ Ethiopia has a highly advanced security and intelligence system. Along the border with Somalia, and in the restive Somali region, the federal forces operate alongside a local police unit known as the Liyu police. The Liyu are particularly heavy-handed and have a highly visible presence across the region. This presence is supported by the nationwide intelligence network, commonly referred to as the 'one to five' network. This informal network means that for every five households, one reports to the government on 'developmental activities'. The Guardian (2015), 'Ethiopia's elections are just an exercise in controlled political participation', 22 May 2015: https://www.theguardian.com/global-development/2015/may/22/ethiopia-electionscontrolled-political-participation (accessed 27 June 2018).

57 The lack of major business assets in Afar means that ARDUF's attacks on foreign interests have mostly been restricted to kidnapping tourists. This includes an incident in 2012, when the group kidnapped two German hostages near the Erte Ale volcano, releasing them a month later. DW (2012), 'Ethiopian rebels announce release of German hostages', 6 March 2012: http://www.dw.com/en/ethiopian-rebels-announce-release-of-german-hostages/a-15790953 (accessed 27 June 2018).

58 The Guardian (2007), 'Ethnic Somali rebels kill 74 at Chinese oilfield in Ethiopia', 25 April 2007: https://www.theguardian.com/world/2007/apr/25/ethiopia (accessed 27 June 2018).
} 

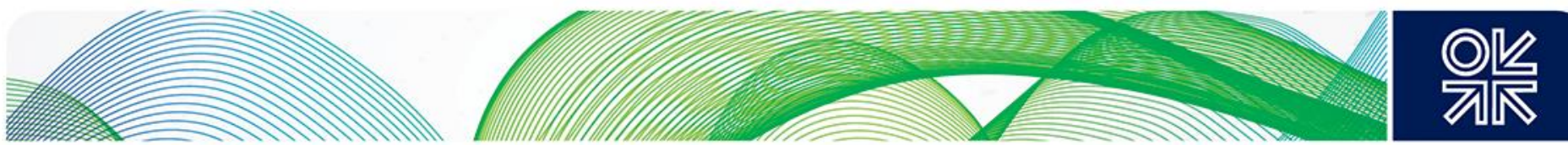

Given their importance to the government, major renewable energy assets would make attractive targets to these groups. ${ }^{59}$ However, an attack on a major renewable energy asset would require a level of operational strategy, planning, and tactical capacity that these groups do not possess and are unlikely to gain over the coming decade. Divisions have emerged within the ONLF, and the group has engaged in peace talks with the government. Meanwhile, ARDUF has not staged a significant attack for years, and it does not appear to have the financing to mount a complex assault on a well-guarded energy asset.

The risk of protests represents the greatest physical threat to renewable energy assets. Between 2015 and 2018, protests recurred in Oromia, Amhara, and to a lesser extent in Addis Ababa and the Somali region (see Figure 4). Protests often attracted thousands of people, and in Oromia and Amhara led to attacks on foreign businesses, particularly those that were either associated with the ruling party or those that were central to the government's economic policy. Such events included throwing stones (or in rare cases in Amhara, grenades) and burning company vehicles; in the worst cases, flower farms and textile factories were burned to the ground in Oromia. ${ }^{60}$

Figure 4: Violent incidents and fatalities in Ethiopia, January 2012 - May 2018

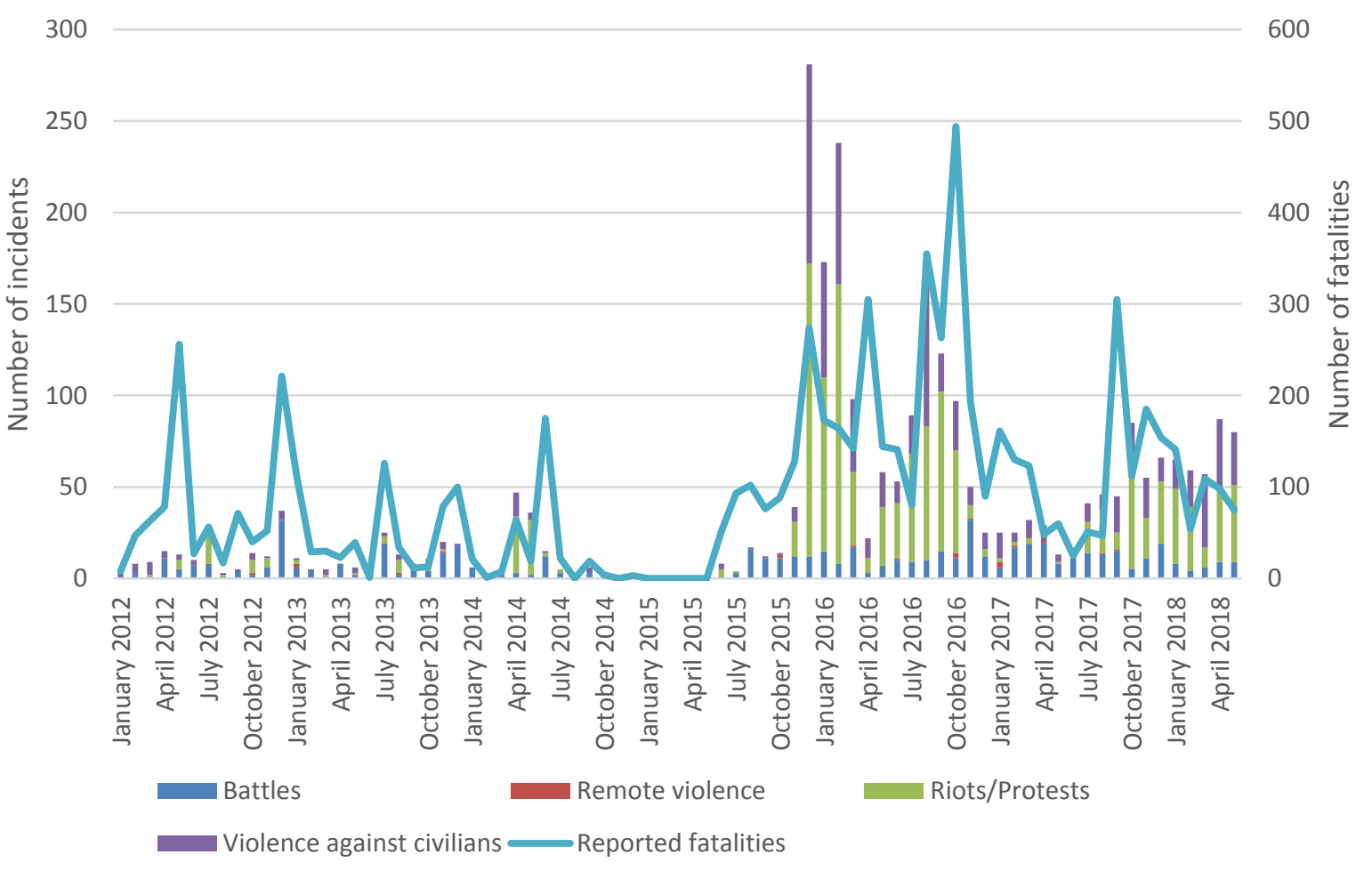

Source: ACLED (The Armed Conflict Location and Event Data Project), 2018.

\footnotetext{
59 In March 2017, the government reported that they had foiled an attack on the GERD. They claim the plot was sponsored by Eritrea. However, there is no evidence that a genuine plot ever existed. At the time, it served as a useful propaganda tool for the government, which was arguing that the widespread protests were stoked by outside forces. Whether genuine or false, the selection of GERD as a target (or fictional target) demonstrates how high-profile these projects are to the government. Bloomberg (2017), 'Eritrea Demies Knowing Group Linked to Ethiopian Dam Plot', 2 March 2017: https://www.bloomberg.com/news/articles/2017-03-02/eritrea-denies-knowledge-of-group-linked-to-ethiopian-dam-plot (accessed 27 June 2018).

${ }^{60}$ Bloomberg (2016), 'Dutch, Israeli Farms in Ethiopia Attacked by Protesters', 1 September 2016: https://www.bloomberg.com/news/articles/2016-09-01/ethiopian-protesters-burn-dutch-owned-flower-farm-in-north (accessed 27 June 2018).
} 

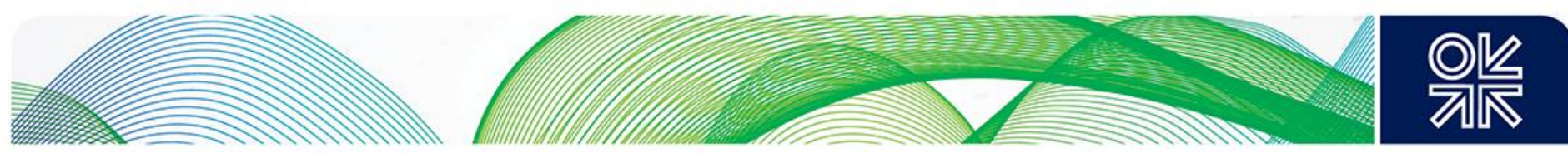

Protests have subsided since Ahmed's appointment as prime minister in April 2018. His efforts to appoint non-Tigrayans to positions of power and to open up space for political opposition will help prevent repeat protests on the same scale. That said, sporadic, localized protests are still likely to occur, particularly over the heavy handedness of security forces. These are unlikely to target or affect foreign businesses.

\subsubsection{Land access and human rights risks}

Utility-scale renewables projects are likely to find themselves facing high reputational and litigation risks, due to their need to partner with the government. International investors have faced criticism for benefiting from the government's controversial land policies. Domestic and international rights groups have accused industrial and agribusiness projects of being complicit in forced relocations and inadequate compensation packages.61 The government has taken steps to improve compensation procedures, but it is highly unlikely that all individuals affected will have given their free, prior, and informed consent.

All energy companies - both utility scale and off-grid -need to be aware of the weak labour rights in the country. There is no minimum wage and occupational health and safety risks can be significant. ${ }^{62}$ Workers - both on site and in company HQs - will have limited rights to privacy due to the pervasiveness of the Ethiopian intelligence service. ${ }^{63}$ Companies will have next-to-no ability to influence the government to improve these areas, and so will therefore need to take extra precautions in order to ensure their assets operate according to international standards.

\subsection{Ethiopia summary}

Although the government is partially liberalizing the power sector, state dominance will remain unchanged. In this environment, large, on-grid projects are likely to be given preference.

Regulations across the energy sector are underdeveloped, introducing a degree of uncertainty for future investors and lengthening negotiation times. Once the government produces key documents - like a standardized PPA - and makes further progress on discussions over the feed-in tariff, it will be easier for projects to apply for financing. Despite these regulatory obstacles, the government is likely to prove an amenable partner. It offers investors a generous incentive package and has a reliable track record on infrastructure development. Equally, the relatively stable security environment means that there are limited risks to physical assets in the country.

However, there are still major obstacles for off-grid solutions. In order to achieve universal access by 2025, the government aims for 35 per cent of electricity to be provided off-grid. However, its attempts to dominate the sector have stifled the innovation seen elsewhere on the continent. As a result, the offgrid and micro-grid sector still does not have the required legislation, and some of the commerciallyproven models used elsewhere may not be replicable.

\footnotetext{
61 The most controversial relocations have occurred in the Gambella region, which is unlikely to be a site for renewables investors. However, this is still a risk they should be aware of. The government is engaging in a programme of relocating rural communities into settlements, in a process known externally as 'villagization' (although this term is controversial in-country). The government claims that these programmes allow for great socio-economic development, as well as food security, for the affected communities. However, families interviewed by international rights groups say that they do not receive adequate compensation, and that the new settlements lack adequate facilities. Investors who are awarded land that was cleared via these programmes face a higher risk of protest. Human Rights Watch (2012), 'Ethiopia: Forced Relocations Bring Hunger, Hardship', 16 January 2012: https://www.hrw.org/news/2012/01/16/ethiopia-forced-relocations-bring-hunger-hardship (accessed 27 June 2018).

62 US Department of State (2017), 'Ethiopia 2017 Human Rights Report', undated https://www.state.gov/documents/organization/277243.pdf (accessed 27 June 2018)

${ }^{63}$ As well as the 'one to five' informant network outlined in footnote 56 , the intelligence service are widely believed to monitor telephone communications. The telecoms sector is a state monopoly, run by EthioTelecom.
} 

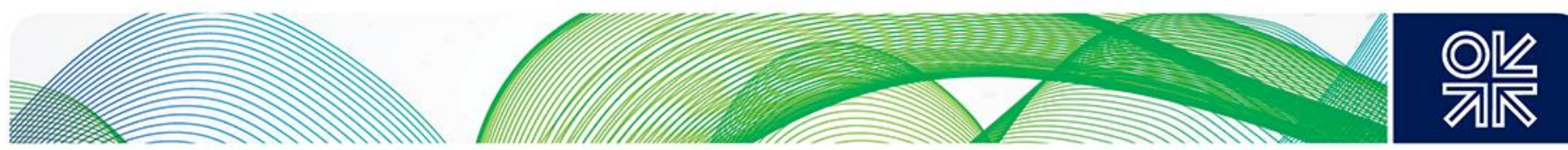

\section{Kenya}

Kenya presents a very different investment environment to Ethiopia. The government has a history of welcoming private investment. Moreover, the power sector is much more influenced by market needs than is the case for the government's overall development vision. Like Ethiopia, renewables are the main contributor to the electricity mix, while ambitious electrification targets focus on renewable energy projects. The legislative environment for foreign investors is relatively well established for both off-grid and micro-grid projects. This reduces regulatory risk. However, the nature of the political system does present challenges - not least over corruption and access to land. As a result, contrary to Ethiopia, risks are higher for large, on-grid projects than they are for off-grid and micro-grid investments.

\subsection{The state of the electricity sector}

Kenya was one of the first countries in sub-Saharan Africa to liberalize its power sector, having allowed Independent Power Producers since the 1990s. ${ }^{64}$ The sector is relatively well developed and has a strong track record. Electricity access rates have risen from 36 per cent of the population in 2014 to 56 per cent in 2016 (see Figure 5). ${ }^{65}$ The government is aiming for universal access by 2020.66

\section{Figure 5: Access to electricity, Kenya}

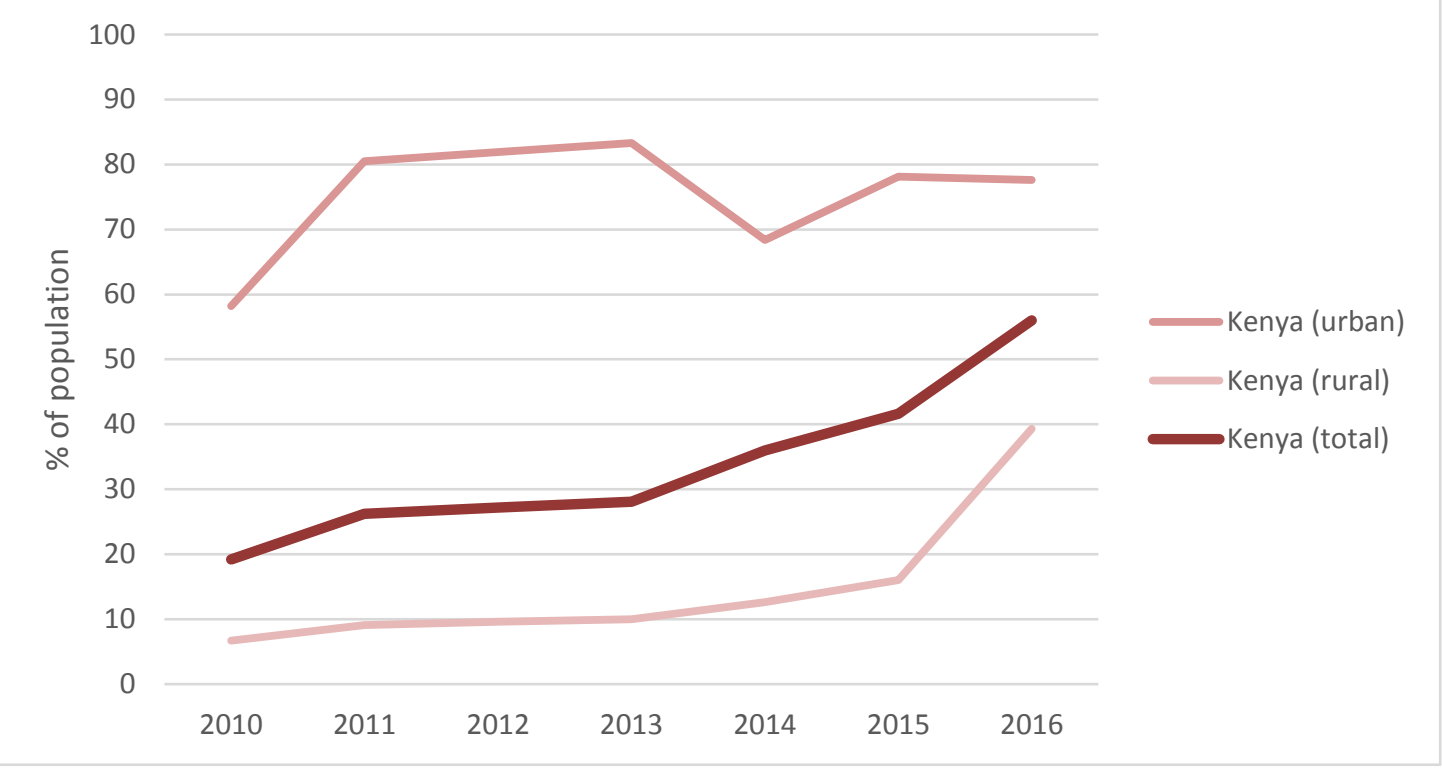

Source: World Bank.

As access increases, so too will demand. Kenya has comparatively high per-capita consumption for the continent - $161 \mathrm{kWh}$, compared to $126 \mathrm{kWh}$ in Nigeria, for example ${ }^{67}$ - and as the fourth-largest economy in Africa it has a burgeoning industrial sector. Peak demand therefore has the potential to double from 2015 levels of $1,800 \mathrm{MW}$ to $2,600-3,600 \mathrm{MW}$ by $2020 .{ }^{68}$ This will exceed the current

\footnotetext{
${ }^{64}$ Power Africa (2017), 'Kenya', December 2017:

https://www.usaid.gov/sites/default/files/documents/1860/KenyaPACFSDEC2017 FINAL.508.pdf (accessed 27 June 2018).

${ }^{65}$ World Bank (undated-1), 'Access to electricity (\% of population)', undated:

https://data.worldbank.org/indicator/EG.ELC.ACCS.ZS?locations=ET-KE\&name desc=false (accessed 27 June 2018).

66 This universal access will be split between $70-80 \%$ of the population receiving power from the grid, with the remaining $20-$

$30 \%$ relying on off-grid systems.

67 Power Africa (2016), 'Development of Kenya's power sector: 2015-2020', May 2016:

https://www.usaid.gov/sites/default/files/documents/1860/Kenya Power Sector report.pdf (accessed 27 June 2018).

${ }_{68}$ Power Africa (2016), 'Development of Kenya's power sector: 2015-2020', May 2016:

https://www.usaid.gov/sites/default/files/documents/1860/Kenya Power Sector report.pdf (accessed 27 June 2018).
} 

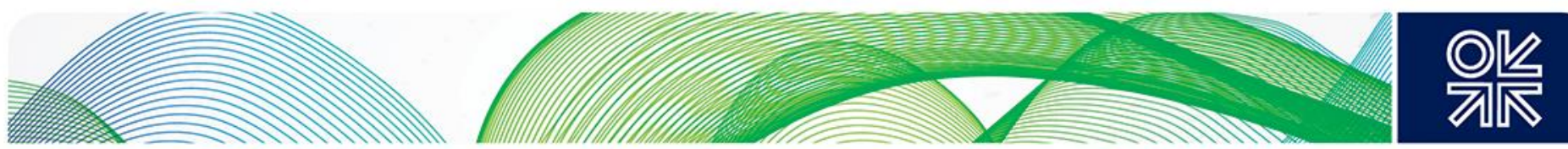

installed capacity of 2,333 MW. ${ }^{69}$ In response, the government is in the process of more than doubling its transmission network from the current $4,149 \mathrm{~km}$.

\section{Figure 6: Electricity consumption by sector, Kenya}

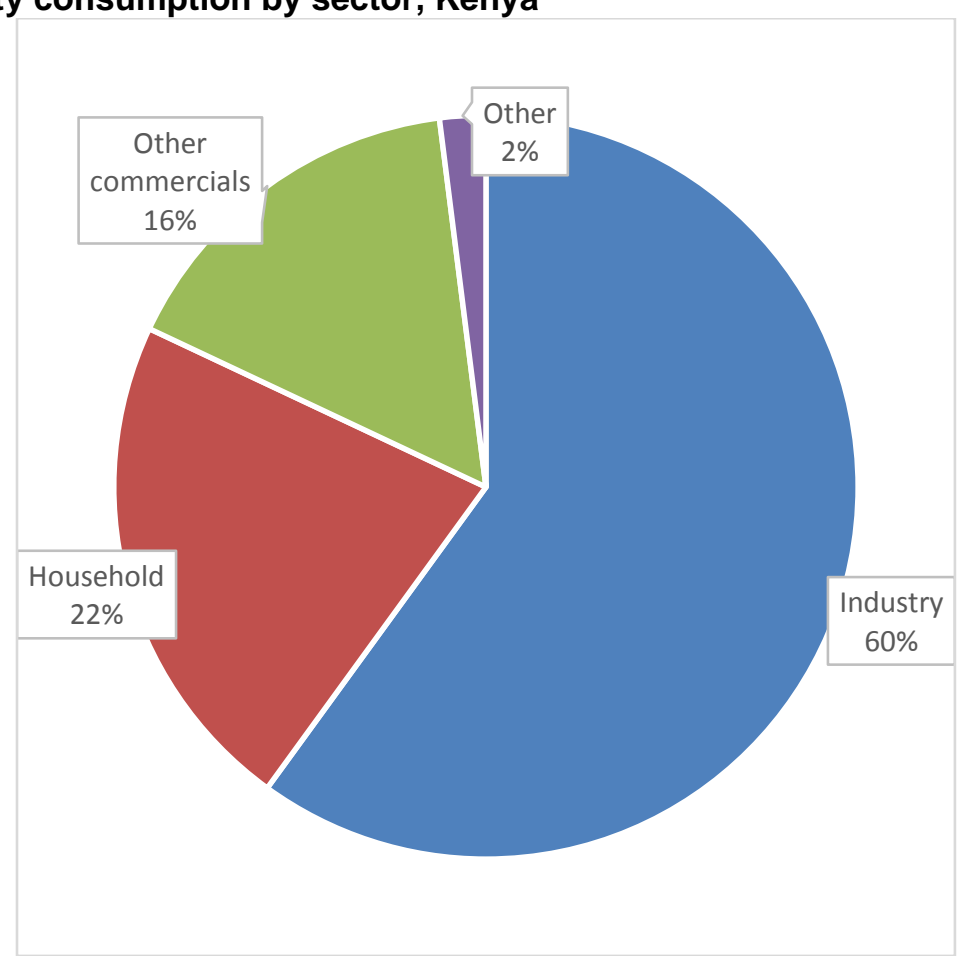

Source: Ministry of Energy and Petroleum Kenya, 2016.

Table 3: Kenya's renewable energy potential

\begin{tabular}{|c|c|c|c|}
\hline Power type & Target & Potential & Region \\
\hline Geothermal & $\begin{array}{l}1.9 \text { GW by } 2016 ; \\
5 \text { GW by } 2030\end{array}$ & $10 \mathrm{GW}$ & Rift Valley \\
\hline Hydropower & 794 MW by 2016 & $\begin{array}{l}1,500 \mathrm{MW} \text {, of which } 1,310 \mathrm{MW} \\
\text { is feasible for projects with a } \\
\text { capacity of at least } 30 \mathrm{MW} \text {. }\end{array}$ & $\begin{array}{l}\text { Lake Victoria basin, Rift Valley } \\
\text { basin, Athi River basin, Tana River } \\
\text { basin, Eqaso Ngiro River basin. }\end{array}$ \\
\hline Solar PV & $\begin{array}{l}423 \mathrm{MW} \text { by } 2016 \\
18 \mathrm{MW} \text { of existing } \\
\text { diesel-run stations } \\
\text { will be retrofitted as } \\
\text { hybrids. }\end{array}$ & $\begin{array}{l}23,046 \mathrm{TWh} / \text { year } \\
\text { One study }{ }^{70} \text { found that under } \\
\text { the current tariffs, } 700 \mathrm{MW} \text { is } \\
\text { economically viable. }\end{array}$ & $\begin{array}{l}\text { Highest irradiation levels in the } \\
\text { north-west and west. }\end{array}$ \\
\hline Wind power & 635 MW by 2016 & $3,000 \mathrm{MW}$ & $\begin{array}{l}\text { Highest in the north-west, central, } \\
\text { and coastal regions. Roughly } 25 \% \\
\text { of the country is suitable for current } \\
\text { wind technology. }\end{array}$ \\
\hline
\end{tabular}

Source: Africa-EU Renewable Energy Cooperation Programme, undated.

\footnotetext{
${ }^{69}$ Ministry of Energy and Petroleum (2017), 'Kenya Country Profile', July 2017: https://eneken.ieej.or.jp/data/7463.pdf (accessed 27 June 2018).

${ }^{70}$ Amy Rose, Robert Stoner, Ignacio Perez-Arriaga (2016), 'Prospects for grid-connected solar PV in Kenya: A systems approach', Applied Energy, Volume 161, pp. 583-90.
} 

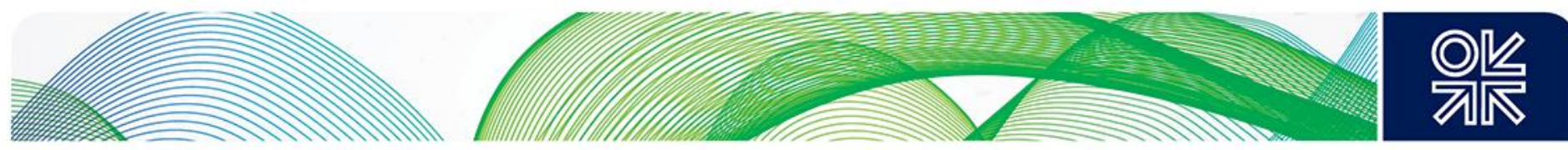

Renewable energy accounts for 87 per cent of Kenya's power mix. ${ }^{71}$ It is at the heart of plans - based on geothermal and hydropower - to expand power generation. Both sources can provide baseload power which would allow for a 100 per cent renewable energy mix. However, the government has not committed to this target. It has plans to develop a coal power plant in Lamu, and the Ministry for Energy has made several statements indicating its intention to use natural gas-powered turbines as a back-up to intermittent power sources.

\section{Off-grid innovation}

A unique feature of Kenya's electricity sector is its innovative use of off-grid. The government has long recognized off-grid as an effective means to rural electrification. There are at least 19 state-owned offgrid power stations in remote locations, primarily in the northern regions of the country. ${ }^{72}$ Private companies are also allowed to generate and distribute power through micro-grids. ${ }^{73}$

They key enabler for the sector was the emergence of mobile money services. M-Pesa and its counterparts Airtel Money and Orange Money have brought millions of Kenyans into the formal economy by allowing them to pay for services using their mobile phones. This has opened up new sales channels, including a pay-as-you-go model for off-grid power. ${ }^{74}$ As of 2017 , Kenya has been home to 40 per cent of the commercial micro-grids operating across sub-Saharan Africa (65 out of 150). The country is likely to account for over a third of new micro-grid developments on the continent to $2021 .{ }^{75}$ These are mostly solar projects - driven by the global drop in prices - but there is also likely to be a growth in micro hydroelectric systems. ${ }^{76}$

\subsection{Government policy}

Of the 2,700 MW capacity additions planned over the next five years, 80 per cent is likely to come from private investment. ${ }^{77}$ This reflects Kenya's reputation as a business-friendly destination. Parties across the political spectrum support private investment, including in the renewable energy sector. ${ }^{78}$ Proprivate investment energy policy is therefore unlikely to see major changes.

\footnotetext{
${ }^{71}$ African Review (2017), 'Kenya: renewables hit 87 per cent of power generation', 28 February 2017: http://www.africanreview.com/energy-a-power/power-generation/kenya-renewables-hit-87-per-cent-of-power-generation (accessed 27 June 2018).

72 These off-grid stations are diesel but will be retrofitted as solar hybrids. Power Africa (2016), 'Development of Kenya's power sector: 2015-2020', May 2016: https://www.usaid.gov/sites/default/files/documents/1860/Kenya Power Sector report.pdf (accessed 27 June 2018).

${ }^{73}$ Ulrich Elmer Hansen (2017), 'Mapping of Solar PV and Wind Energy Markets in Kenya: Current State and Emerging Trends', Technical University of Denmark, August 2017: http://irekproject.net/files/2017/08/Final-report-UEHansen.pdf (accessed 27 June 2018)

${ }^{74}$ A study by TFE Consulting in YEAR estimated that by $2021,2,000-3,000$ of the 7,000 micro-grids in sub-Saharan Africa will be in Kenya. By comparison, India, which has a population ten times larger than Kenya and 'one of the world's most aggressive micro-grid expansion policies' will only develop 10,000 micro-grids over the same period. TFE Consulting (2017), 'Kenya: The World's Microgrid Lab', December 2017: https://www.tfeconsulting.com/ website/wp-content/uploads/2017/12/TFE ReportKenya-new.pdf (accessed 27 June 2018); Ulrich Elmer Hansen (2017), 'Mapping of Solar PV and Wind Energy Markets in Kenya: Current State and Emerging Trends', Technical University of Denmark, August 2017: http://irekproject.net/files/2017/08/Final-report-UEHansen.pdf (accessed 27 June 2018)

75 TFE Consulting (2017), 'Kenya: The World's Microgrid Lab', December 2017: https://www.tfeconsulting.com/ website/wpcontent/uploads/2017/12/TFE Report-Kenya-new.pdf (accessed 27 June 2018).

${ }^{76}$ There are roughly 55 river sites that are suitable for these systems, which have to have capacities of $10 \mathrm{MW}$ or less. AfricaEU Renewable Energy Cooperation Programme (undated), 'Kenya: Renewable Energy Potential', undated: https://www. africaeu-renewables.org/market-information/kenya/renewable-energy-potential/ (accessed 27 June 2018).

77 Power Africa (2016), 'Development of Kenya's power sector: 2015-2020', May 2016: https://www.usaid.gov/sites/default/files/documents/1860/Kenya Power Sector report.pdf (accessed 27 June 2018).

${ }^{78}$ SE4All (2016), 'Sustainable Energy for All: Kenya's Investment Prospectus', 21 April 2016:

http://www.ke.undp.org/content/kenya/en/home/library/environment energy/sustainable-energy-for-all-kenya-investmentprospectus.html (accessed 27 June 2018).
} 

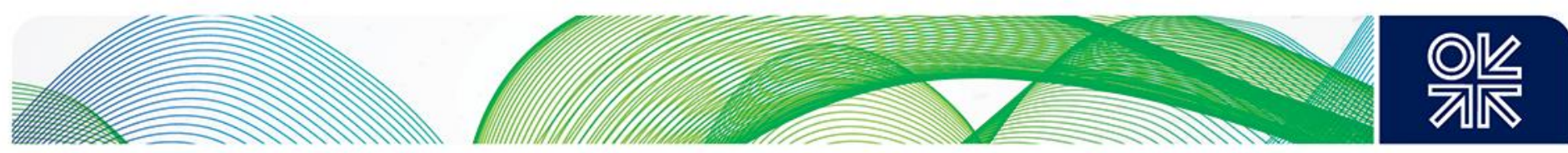

The sector is further protected from political fluctuations by the partial privatization of utilities. Only the Geothermal Development Company and the Kenya Electricity Transmission Company are wholly stateowned enterprises. That said, political risk is still high when compared to Ethiopia due, in large part, to the high levels of ethnic competition throughout the system.

\subsubsection{An unstable political environment}

A major concern of investors in Kenya is the frequency and scale of political crises. In 2007-8, political violence killed over 1,000 people and displaced over half a million. ${ }^{79} \mathrm{~A}$ decade later, elections in 2017 led to a Supreme Court intervention that annulled the election result and ground the country to a sixmonth standstill while the election was re-run. ${ }^{80}$ During election cycles, GDP growth dips dramatically as investors tend to hold off on decisions, fearing property damage and physical risk to staff, as well as the potential for contract renegotiation or regulatory changes should power change hands.

There is no immediate risk of a repeat outbreak of violence comparable to that of 2007-8. However, the root causes of that civil conflict remain in place. Kenya has a long history of tribalism and corruption. Political leaders have a tendency to use positions of power to allocate resources and opportunities to their own ethnic group. There are over 40 ethnic groups, the largest of which, the Kikuyu, only makes up 22 per cent of the population. ${ }^{81}$ The lack of a clear ethnic majority means that in order to win power, leaders and political parties have to make alliances to form coalitions, and these change at almost every election cycle.

The Kikuyu have a historic rivalry with the Kalenjin in the Rift Valley. When these groups are opposed - as in 2007 - the risk of violence is highest. Since 2013, these groups have been allied under the Jubilee Alliance, led by President Uhuru Kenyatta (Kikuyu) and Deputy President William Ruto (Kalenjin). President Kenyatta is constitutionally obliged to step down in 2021. When he does so, Deputy President Ruto is hoping to be the flagbearer for Jubilee. However, it remains unclear if Ruto will be able to hold the coalition together, and if he will be able to persuade the historically-dominant Kikuyu to vote for him. As elections draw closer, the business of alliance forming is likely to dominate the political sphere. This is likely to increase corruption and slow down decision making.

\subsection{Regulatory environment and institutional reliability}

The unstable political environment has numerous knock-on effects when dealing with government bureaucracy. As noted, corruption risks are particularly high and state institutions can become hijacked by politicking, reducing their effectiveness. This includes efforts to expand the power infrastructure network, which is essential for many on-grid proposals.

That said, the government has created a relatively strong legislative and regulatory framework for renewable energy investors. Unlike Ethiopia, this includes a number of targeted policies such as feedin tariff and net metering proposals.

\footnotetext{
${ }^{79}$ Al Jazeera (2013), ‘Kenya: What went wrong in 2007?', 3 March 2013:

https://www.aljazeera.com/indepth/features/2013/03/201333123153703492.html (accessed 27 June 2018).

80 Bloomberg (2017), 'Kenya Faces Prolonged Uncertainty After Election Is Annulled', 1 September 2017:

https://www.bloomberg.com/news/articles/2017-09-01/kenya-plunges-into-turmoil-after-court-annuls-presidential-vote

(accessed 27 June 2018).

${ }^{81}$ Minorities at risk (undated), 'Assessment for Kikuyu in Kenya', undated

http://www.mar.umd.edu/assessment.asp?groupld=50103 (accessed 27 June 2018).
} 

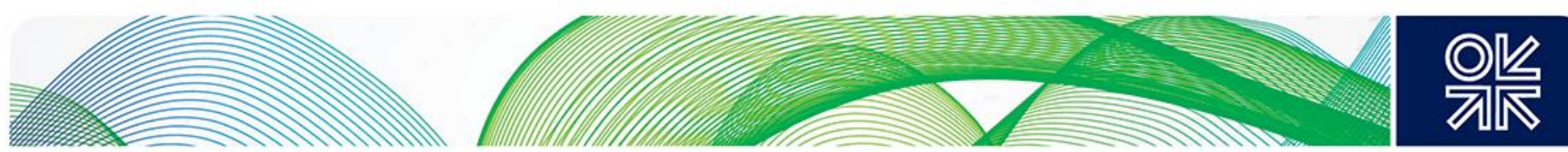

Figure 7: Renewable energy policies, Kenya

\begin{tabular}{|c|c|c|c|c|c|c|c|c|c|c|}
\hline \multirow[b]{2}{*}{ Country } & \multicolumn{2}{|c|}{ Targets } & \multicolumn{5}{|c|}{ Regulatory policies } & \multicolumn{3}{|c|}{ Fiscal incentives and public financing } \\
\hline & $\begin{array}{l}\text { Renewable } \\
\text { energy target }\end{array}$ & $\begin{array}{l}\text { Renewable } \\
\text { energy in } \\
\text { S INDC or NDC }\end{array}$ & $\begin{array}{l}\text { FiT/premium } \\
\text { payment }\end{array}$ & Net metering & $\begin{array}{l}\text { Transport } \\
\text { obligation/ } \\
\text { mandate }\end{array}$ & $\begin{array}{l}\text { Heat } \\
\text { obligation/ } \\
\text { mandate }\end{array}$ & Tendering & $\begin{array}{l}\text { Reductions in } \\
\text { sales, energy, } \\
\text { VAT or other } \\
\text { taxes }\end{array}$ & $\begin{array}{l}\text { Energy } \\
\text { production } \\
\text { payment }\end{array}$ & $\begin{array}{l}\text { Public } \\
\text { investment, } \\
\text { loans, grants, } \\
\text { capital } \\
\text { subsidies or } \\
\text { rebates }\end{array}$ \\
\hline Ethiopia & $x$ & $x$ & & & $x$ & & & $x$ & & $x$ \\
\hline Kenya & $x$ & $x$ & $x$ & $x$ & & $x$ & (Historical) & $x$ & $x$ & $x$ \\
\hline
\end{tabular}

Source: IRENA, 2017.

\subsubsection{Legislative and regulatory structure}

Investors will need to deal with the following bodies:

- Ministry of Energy and Petroleum ${ }^{82}$ Formulates policy and sets the strategic direction for the sector.

- Energy Regulatory Commission $(E R C)^{83}$ The independent regulator that reviews tariffs, drafts and implements regulations, and issues permits and licences.

- Rural Electrification Authority (REA) ${ }^{84}$ Implements rural electrification projects, including operating the public micro-grids in remote areas. It is 100 per cent state owned.

- Kenya Electricity Generating Company (KenGen) ${ }^{85}$ Generates the majority of electric power in the country. It is 70 per cent state owned.

- Kenya Electricity Transmission Company (KETRACO) ${ }^{86}$ Responsible for the construction and operation of new transmission lines. It is 100 per cent state owned.

- Kenya Power and Lighting Company (Kenya Power/KPLC) ${ }^{87}$ Responsible for the transmission and distribution of power. It has a monopoly over distribution and retail, although this will be removed when the new Energy Bill passes (expected later in 2018). It is 50.1 per cent state owned.

Plans for the sector are laid out in key policy documents, such as Vision 2030, the National Energy and Petroleum Plan 2015, and the 1997 Rural Electrification Master Plan. ${ }^{88}$ These policies have been translated into the following key laws and regulations:

- The Sessional Paper No. 4, 2004 on Energy: The Sessional Paper launched a restructuring of the energy sector, leading to the creation of the Energy Regulatory Commission (ERC) and the Rural Electrification Authority (REA), as well as the privatization of the Kenya Electricity Generating

\footnotetext{
${ }^{82}$ Ministry of Energy and Petroleum (undated), 'Home', undated: http://energy.go.ke/ (accessed 27 June 2018 ).

${ }^{83}$ Energy Regulatory Commission (undated), 'Home', undated: https://www.erc.go.ke/ (accessed 27 June 2018 ).

${ }^{84}$ REA (undated), 'About REA', Rural Electrification Authority, undated: http://www.rea.co.ke/ (accessed 27 June 2018).

${ }^{85}$ KenGen (undated), 'Brief About Us', undated: http://www.kengen.co.ke/ (accessed 27 June 2018).

${ }^{86}$ KETRACO (undated), 'Home', undated: https://www.ketraco.co.ke/ (accessed 27 June 2018).

${ }^{87}$ Kenya Power (undated-1), 'Kenya Power', (home page), undated: http://www.kplc.co.ke/ (accessed 27 June 2018); The Star (2018a), 'Kenya Power monopoly to end if energy bill is passed', 16 February 2018: https://www.thestar.co.ke/news/2018/02/16/kenya-power-monopoly-to-end-if-energy-bill-is-passed c1715568 (accessed 27 June 2018 ). 88 The Rural Electricity Plan (the plan itself is not online, this link has detail): http://www.climatesolver.org/blog/glimpse-ruralelectrification-program-kenya; Vision 2030: http://vision2030.go.ke/; The 2015 Energy Bill: http://kenyalaw.org/kl/fileadmin/pdfdownloads/bills/2015/Energy_Amendment_Bill2015.pdf.
} 

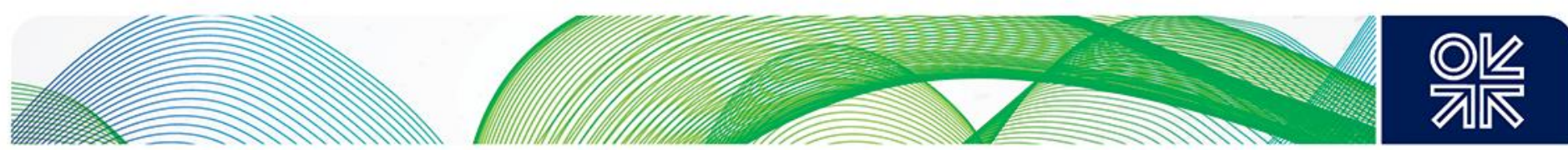

Company (KenGen). It encouraged the use of renewables, created a framework for public-private partnerships, and introduced feed-in tariffs. ${ }^{89}$

- The Energy Act 2006: The Act consolidated the Electric Power Act 1997 and the Petroleum Act, Cap 116, and it provides for the responsibilities of the ERC and REA. ${ }^{90}$ The 1997 Act had authorized IPPs to supply the national grid, but it did not adequately cover decentralized systems. ${ }^{91}$

- The Energy Bill 2017: A replacement for the 2006 Act. In 2017, the Bill was passed by Parliament but rejected by the president; it is highly likely to pass in $2018 .{ }^{92}$ The Bill contains a number of key changes:

- Removing Kenya Power's monopoly, to make the distribution market more competitive. ${ }^{93}$

- Replacing the feed-in tariff policy with competitive auctions.

- Introducing net-metering to support private, off-grid consumers. ${ }^{94}$

- Introducing royalties of between 1 and 2.5 per cent for geothermal producers for the first decade, after which they will rise to up to 5 per cent. ${ }^{95}$

- Key regulations include:

$\circ \quad$ The Energy (Electricity Licensing) Regulations, 2012: which cover permitting (for projects below $3 \mathrm{MW}$ capacity) and licensing (for projects above $3 \mathrm{MW}$ ) requirements. ${ }^{96}$

- The Energy (Complaints and Dispute Resolution) Regulations, 2012: which lay out the dispute resolution methods used by the ERC in the event of a dispute between a licensee and customers. ${ }^{97}$

Despite the delays over the new Energy Bill, the presence of such a well-developed regulatory framework is a strong draw for international investors. Crucially, Kenyan power purchase agreements conform to a standardized model following government guidance. This provides additional contract certainty for investors and also reduces regulatory uncertainty for utility-scale investors by providing terms under which they sell their power back to the grid. Additionally, under a collection of Legal Notices

\footnotetext{
${ }^{89}$ Ministry of Energy (2004), Sessional Paper No. 4 on Energy, Government of Kenya: https://renewableenergy.go.ke/downloads/policy-docs/sessional paper 4 on energy 2004.pdf

${ }^{90}$ Ministry of Energy and Petroleum (2006), The Energy Act, No. 12 of 2006, Government of Kenya.

${ }^{91}$ Africa-EU Renewable Energy Cooperation Programme (undated), 'Kenya: Renewable Energy Potential', undated: https://www.africa-eu-renewables.org/market-information/kenya/renewable-energy-potential/ (accessed 27 June 2018).

${ }_{92}$ The president reportedly rejected the bill over a clause that stipulated Kenya Power would have to pay customers for any outage longer than three hours. Kaplan \& Stratton (2018), 'A Year in Review - Looking back at the legislative developments of 2017', February 2018: http://www.kaplanstratton.com/wp-content/uploads/2018/02/A-Year-in-Review-Newsletter.pdf (accessed 27 June 2018)

${ }^{93}$ Republic of Kenya (2015), The Energy (Amendment) Bill, 2015; Ibrahim Olalekan Abdulganiyu (2017), 'Possibilities and barriers for increasing renewable power generation in Kenya and Tanzania', 2017:

https://www.doria.fi/bitstream/handle/10024/135170/Master Thesis Ibrahim Abdulganiyu Final.pdf?sequence=2 (accessed 27 June 2018)

${ }^{94}$ Rödl \& Partner (2016), 'Solar power, the next frontier for Kenya's renewable energy sector', July 2016:

https://www.roedl.com/insights/erneuerbare-energien/2016-07/solar-power-frontier-kenya-renewable-energy-sector (accessed 27 June 2018)

${ }^{95}$ Bloomberg (2018b), 'Kenya Plans Royalty for Geothermal Producers in Energy Bill', 14 February 2018: https://www.bloomberg.com/news/articles/2018-02-14/kenya-proposes-royalty-for-geothermal-producers-in-energy-bill (accessed 27 June 2018).

${ }^{96}$ Ministry of Energy and Petroleum (2006), The Energy Act, No. 12 of 2006, Government of Kenya. Ministry of Energy and Petroleum (2012), The Energy (Electricity Licensing) Regulations 2012; Ibrahim Olalekan Abdulganiyu (2017), 'Possibilities and barriers for increasing renewable power generation in Kenya and Tanzania': https://www.doria.fi/bitstream/handle/10024/135170/Master Thesis Ibrahim Abdulganiyu Final.pdf?sequence=2

${ }^{97}$ Getting the Deal Through (2017b), 'Electricity Regulation: Kenya', November 2017:

https://gettingthedealthrough.com/area/12/jurisdiction/44/electricity-regulation-kenya/ (accessed 27 June 2018).
} 

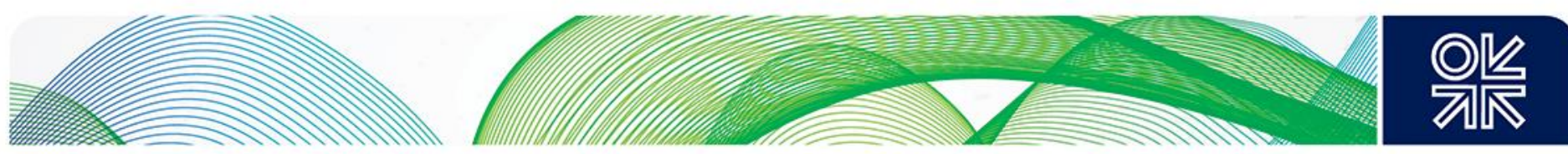

approved in 2015, renewable energy projects receive a number of tax exemptions - including withholding tax, stamp duty, export duty, and VAT and customs tax on imports. ${ }^{98}$

\section{Impact of the proposed regulatory changes}

Renewable energy projects under $50 \mathrm{MW}$ can currently apply for feed-in tariffs, which were first introduced in 2008 and last revised in $2012 .{ }^{99}$ This allows power producers to sell their electricity to an off-taker for a fixed price, over a set period. This system is considered beneficial as it allows investors to guarantee their profit margins. However, in Kenya it has caused delays during licensing discussions and led to the growth of speculators in the market. ${ }^{100}$

The government will replace the current feed-in tariffs with a system of competitive auctions under The Energy Bill 2017. Auctions have become increasingly popular with governments that are seeking to reduce consumer energy prices as they foster greater competition over pricing, in theory producing a better result for end-users. ${ }^{101}$ For investors, auctions still provide price stability, but they are likely to have to offer lower tariffs, potentially reducing their profit margins. That said, competitive auctions have proved highly effective elsewhere on the continent, including South Africa and Zambia, where they have produced record low tariffs. Despite these low prices, the dramatic cost reduction in solar equipment, in particular, means that these projects are still economically viable. They are therefore unlikely to dampen investor interest.

\subsubsection{Inefficient bureaucracy}

The tariff system has been particularly challenging for off-grid and micro-grid projects, where it has resulted in lengthy negotiations for licences. The government currently subsidizes power, which allows for a universal rate that is lower than most private companies' generation costs. This subsidy is not a significant cause of concern for on-grid operators, who agree a fixed sale price with the off-taker. Should the government remove the subsidy, the cost would go up for end-users but would have no effect on the generator. ${ }^{102}$

The subsidy system is problematic for off-grid private operators, who sell their electricity directly to the consumer. They generally charge a higher tariff than the universal rate in order to cover generation costs. ${ }^{103}$ They offset the high tariff with a low rate for connection, based on the assumption that usage

\footnotetext{
${ }^{98}$ Berwin Leighton Paisner (2017), 'Power to Africa Volume 3: Kenya - Part 1', June 2017: http://www.blplaw.com/media/howcan-we-help-you/Power to Africa Volume 3 - Kenya - Part 1.pdf (accessed 27 June 2018).

${ }_{99}$ PV Tech (2014), 'Kenya's FiT-approved solar pipeline reaches 750 MW', 5 March 2014: https://www.pvtech.org/news/kenyas fit approved solar pipeline reaches 750mw (accessed 27 June 2018); Ulrich Elmer Hansen (2017), 'Mapping of Solar PV and Wind Energy Markets in Kenya: Current State and Emerging Trends', Technical University of Denmark, August 2017: http://irekproject.net/files/2017/08/Final-report-UEHansen.pdf (accessed 27 June 2018).

${ }^{100}$ Given the rapidly falling price of equipment, companies have been agreeing a FiT with the government, and then waiting for their equipment costs to fall in order to ensure a greater profit. Newsbase (2016), 'Kenya Moves To Swap FiTs For Competitive Auctions', Week 14, Issue 531, 18 October 2016: https://newsbase.com/topstories/kenya-moves-swap-fits-competitive-auctions (accessed 27 June 2018).

${ }^{101}$ It is worth noting that although many governments are replacing feed-in tariffs with competitive auctions, as seen in Kenya, this is not likely to occur in Ethiopia in the immediate future. Government-set feed-in tariffs allow the state to ensure a fixed, predictable price, whereas auctions are more in line with free-market principles. Given that the liberalization of the energy market is very recent in Ethiopia, the government is therefore likely to stick with a feed-in tariff model.

${ }^{102} \mathrm{~A}$ similar subsidy system is in place in Ethiopia, with the same implications for investors.

${ }^{103}$ Ministry of Energy and Petroleum (2016), 'Current activities and challenges to scaling up mini-grids in Kenya', May 2016 https://www.esmap.org/sites/esmap.org/files/DocumentLibrary/ESMAP Kenya\%20Roundtable May\%202016 formatted-v4.pdf (accessed 27 June 2018); GIZ (2015), 'How do we license it? A guide to licensing a mini-grid energy service company in Kenya', July 2015: https://www.giz.de/en/downloads/GIZ2015-ProSolar-Licensing-Guidebook.pdf (accessed 27 June 2018).
} 

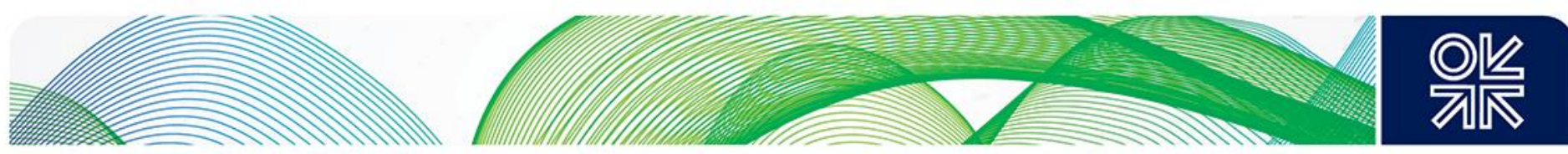

will be high. The resulting tension has led to the government rejecting several proposals for commercial tariffs, significantly delaying project implementation and risking investor profit margins. ${ }^{104}$

Even for larger projects, progress can be slow. Vestas Wind Systems first signed their PPA in 2010, but construction on the Lake Turkana Wind Power project did not begin until 2016.105 While there is a strong government impetus behind these projects, they are still stymied by the same long negotiations and high transaction costs seen by other infrastructure developers. The politicization of negotiations can also add to the challenge of finding foreign backers for projects. For example, in 2012, the World Bank withdrew from a deal to guarantee funding for the Lake Turkana Wind Project due to a disagreement over the terms of the PPA. ${ }^{106}$

\subsubsection{Risks from the transmission and distribution expansions}

KETRACO is responsible for all new transmission lines. New renewables projects are likely to be far from the grid, and it requires a significant effort from KETRACO to build the infrastructure necessary to offload the new facility's power. This has presented a significant obstacle for the Lake Turkana Wind Power project, which was completed in early 2017 but will only be connected to the grid, at the earliest, in September 2018. ${ }^{107}$

By definition, off-grid and micro-grid operators are spared transmission difficulties. However, they face a moderate risk of competition from the ongoing expansion of the distribution network. Kenya Power, the owner of the distribution network, is carrying out the 2014 Last Mile Connectivity Program, which connects all customers within 600 metres of an existing transformer at a subsidized price. ${ }^{108}$ Most of these connections occur under the Single Wire Earthing Return system, whereby thinner, lighter cables are used. ${ }^{109}$ This reduces the cost of both implementation and the final tariff which, as discussed, is already lower than most private company tariffs. There is currently little interaction between Kenya Power and off-grid private proposals. ${ }^{110}$ As a result, it is possible that distribution networks will be

\footnotetext{
104 Ulrich Elmer Hansen (2017), 'Mapping of Solar PV and Wind Energy Markets in Kenya: Current State and Emerging Trends', Technical University of Denmark, August 2017: http://irekproject.net/files/2017/08/Final-report-UEHansen.pdf (accessed 27 June 2018).

${ }^{105}$ Anton Eberhard et al. (2016), Independent Power Projects in Sub-Saharan Africa: Lessons from Five Key Countries. Directions in Development--Energy and Mining, Washington DC: World Bank; Ministry of Energy and Petroleum (2013), 'Wind Sector Prospectus - Kenya', September 2013: https://www.scribd.com/document/318859565/Wind-Sector-Prospectus-Kenya (accessed 27 June 2018); Ulrich Elmer Hansen (2017), 'Mapping of Solar PV and Wind Energy Markets in Kenya: Current State and Emerging Trends', Technical University of Denmark, August 2017: http://irekproject.net/files/2017/08/Final-reportUEHansen.pdf (accessed 27 June 2018)

${ }^{106}$ The clause the bank particularly objected to is known as the 'take or pay' provision. This locked the government into paying for power, even if it could not be absorbed into the grid. The World Bank argued that this was unfair on the Kenyan taxpayer, and it therefore withdrew its support for the project. Business Daily (2012), 'Kenya Power's deal that forced World Bank out of wind farm', 21 October 2012: https://www.businessdailyafrica.com/news/Kenya-Power-deal-that-forced-World-Bank-out-ofwind-farm-/539546-1538602-7twc4q/index.html (accessed 27 June 2018).

${ }^{107}$ This has not resulted in major financial losses to the company, due to the aforementioned 'take or pay' clause. The government is paying a hefty fine, which is equivalent to the agreed value of the power produced. Renewables Now (2017a), 'Transmission link delays launch of Kenya's 310-MW wind farm - report', 8 June 2017

https://renewablesnow.com/news/transmission-link-delays-launch-of-kenyas-310-mw-wind-farm-report-571467/ (accessed 27 June 2018); Reuters (2018a), 'Kenya says major wind power line 70 percent finished, to be complete by June', 8 January 2018 : https://www.reuters.com/article/kenya-electricity/kenya-says-major-wind-power-line-70-percent-finished-to-be-complete-byjune-idUSL8N1P329N (accessed 27 June 2018)

${ }^{108}$ Kenya Power (undated-2), 'Last Mile Connectivity', undated: http://www.kplc.co.ke/content/item/1120/last-mile-connectivity (accessed 27 June 2018)

${ }^{109}$ Business Daily (2015), 'Kenya Power to cut cost of connecting rural homes to grid', 26 December 2014: https://www.businessdailyafrica.com/Kenya-Power-to-cut-cost-of-connecting-rural-homes-to-grid/-/539546/2569562/-/ob8c12z/lindex.html (accessed 27 June 2018); IRENA (2016), 'Solar PV in Africa: Costs and Markets', September 2016: https://www.africa50.com/fileadmin/uploads/africa50/Documents/Knowledge Center/IRENA Solar PV Costs Africa 2016.pdf (accessed 27 June 2018).

${ }^{110}$ Power Africa (2016), 'Development of Kenya's power sector: 2015-2020', May 2016:

https://www.usaid.gov/sites/default/files/documents/1860/Kenya Power Sector report.pdf (accessed 27 June 2018).
} 

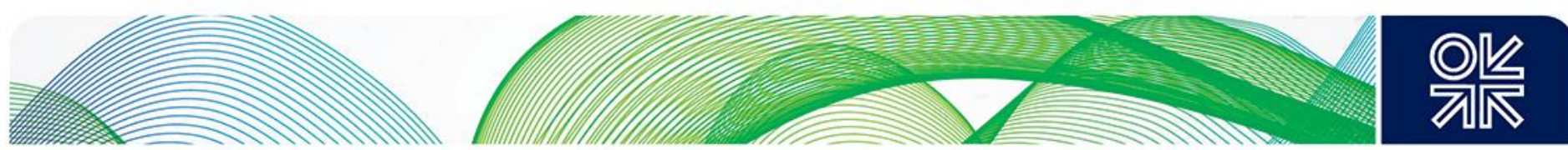

expanded to areas already under proposal for off-grid or mini-grid solutions. This could pose a challenge to private companies who may find themselves competing for access.

\subsubsection{Corruption}

Corruption is a significant risk in Kenya and over 30 per cent of businesses expect to have to pay bribes. ${ }^{111}$ Government officials are often implicated, and it is not uncommon to hear of scandals involving millions of dollars in lost funds. To give a recent example, in May 2018, 39 government officials and 14 private citizens were arrested over embezzlement and procurement fraud in the National Youth Service, amounting to losses of over USD100 million. ${ }^{112}$

Corruption is widespread across Kenyan institutions including the judiciary, security forces, and land administration. ${ }^{113}$ On Transparency International's Corruption Perceptions Index, Kenya is consistently ranked as one of the poorest performers worldwide. In 2017 it was ranked 143 out of 180 countries assessed (see Table 4).

Table 4: Corruption in East Africa

\begin{tabular}{|l|l|l|l|}
\hline Country & TI score & Rank & Rank in sub-Saharan Africa \\
\hline Ethiopia & 35 & 107 & 18 \\
\hline Kenya & $\mathbf{2 8}$ & $\mathbf{1 4 3}$ & $\mathbf{2 8}$ \\
\hline Uganda & 26 & 151 & 33 \\
\hline
\end{tabular}

Source: Transparency International, 2017.

According to Kenya's corruption watchdog, the Ethics and Anti-Corruption Commission, 70 per cent of corruption relates to procurement. ${ }^{114}$ This usually involves politically affiliated businesses being granted lucrative contracts at inflated prices. Foreign investors can be implicated if they partner with these firms or if their government suppliers try to take advantage of the lucrative opportunity.

All investors will face corruption risks when dealing with public institutions. Large industrial-scale projects are likely to face higher bribery demands, including to access land, and may be expected to partner with politically affiliated suppliers.

\subsection{Risks associated with physical assets}

Kenya presents several challenges associated with land access. Securing land comes with high corruption risks, and resettlement processes rarely run smoothly. Large-scale projects also face a high risk of violent protests over job creation, and these can result in property damage and project delays. These risks are significantly lower for off-grid investments, which have a smaller physical presence.

\footnotetext{
111 GAN Business Anti-Corruption Portal (2017), 'Kenya Corruption Report', June 2017: https://www.business-anticorruption.com/country-profiles/kenya/ (accessed 27 June 2018); World Bank Group, Enterprise Surveys (2013), 'Kenya', 20013: http://www.enterprisesurveys.org/data/exploreeconomies/2013/kenya (accessed 27 June 2018).

112 DW (2018), 'Massive corruption case grips Kenya, prosecution charges suspects', 28 May 2018: http://www.dw.com/en/massive-corruption-case-grips-kenya-prosecution-charges-suspects/a-43964072 (accessed 27 June 2018).

${ }^{113}$ GAN Business Anti-Corruption Portal (2017), 'Kenya Corruption Report', June 2017: https://www.business-anticorruption.com/country-profiles/kenya/ (accessed 27 June 2018).

${ }^{114}$ Forbes (2015), 'Corruption and “Tenderpreneurs” Bring Kenya's Economy To Its Knees', 1 December 2015 https://www.forbes.com/sites/mfonobongnsehe/2015/12/01/corruption-and-tenderpreneurs-bring-kenyas-economy-to-its-knees/ (accessed 27 June 2018).
} 

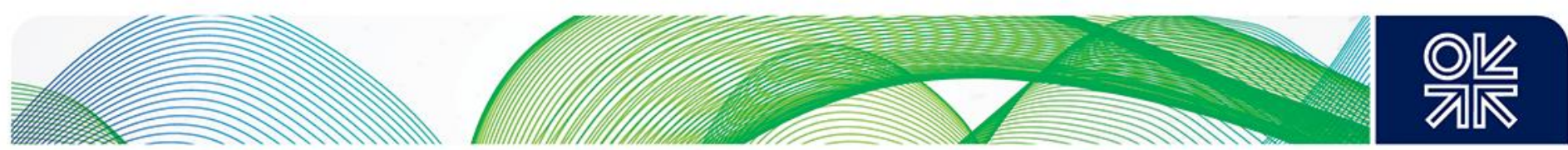

\subsubsection{Land access}

Land is a highly valued commodity, particularly in areas of the Rift Valley which are either densely populated or part of pastoralist migration routes, but ownership can be hard to establish. ${ }^{115}$ Speculation is also rife, pushing up the cost of land in areas around planned infrastructure routes or private developments.

Despite efforts to reform the Land Registry, land titles are still rare. Moreover, the National Lands Commission (NLC) is frequently cited as being one of the most corrupt institutions nationwide. Cordisons International, a US wind power investor, is currently involved in a court battle over land access in Lamu county. Cordisons claims it was authorized to proceed with an 11,000 acre wind project, but that the NLC later reallocated 3,200 acres of the plot to a local firm Kenwind. ${ }^{116}$ This highlights how, for large-scale projects, gaining enough land can be costly and time consuming. Equally, where there is enough land available, it is likely to be far from the grid, ${ }^{117}$ leading to delays similar to those seen at the Lake Turkana Wind Power project.

Once the government has granted land access, companies are likely to face delays and complaints over resettlement plans. In early 2016, the 61 MW Kinangop wind project was cancelled, primarily due to delays caused by local opposition to land usage. ${ }^{118}$ The local Maasai community claimed not to have been fairly compensated for land and that the turbines were too close to houses. ${ }^{119}$ The project investors have since complained to the International Chamber of Commerce, demanding that Kenya repay their lost investment of USD66 million. ${ }^{120}$ The aforementioned Kenwind project in Lamu has faced similar problems, resulting in a compensation dispute with 600 farmers, who are demanding nearly USD 15,000 per acre for an unspecified area of the 3,200 acre plot. ${ }^{121}$

Off-grid and micro-grid operators are highly unlikely to face such controversies over land use. Due to their distributed nature, they do not have the same land requirements. That said, it is still important for these players to maintain strong community relations, as they will rely on community structures to ensure their social licence to operate.

\subsubsection{Security risks}

Large-scale developers are also likely to face risks of violent protests over the local population's expectation for economic benefits (see Figure 8). In 2013, for example, 400 local residents stormed

\footnotetext{
${ }^{115}$ In colonial times, there was a large titling programme but it's too costly. Most people can't afford to update titles. Plus, in rural areas, it's held by communities. The Economist (2016), 'Title to come', 16 July 2016: https://www.economist.com/middleeast-and-africa/2016/07/16/title-to-come (accessed 27 June 2018).

${ }^{116}$ The Star (2018b), 'Land battles, tender wars and cost secrets: Did Kenya bite off too much with energy projects?' 2 June 2018: https://www.the-star.co.ke/news/2018/06/02/land-battles-tender-wars-and-cost-secrets-did-kenya-bite-off-toomuch c1766702 (accessed 27 June 2018).

17 Capital Business (2015), 'The state of renewable energy in Kenya', 17 November 2015:

https://www.capitalfm.co.ke/business/2015/11/the-state-of-renewable-energy-in-kenya/ (accessed 27 June 2017).

${ }^{118}$ African Business (2016), 'Africa's largest wind farm set to power Kenya', 22 June 2016:

http://africanbusinessmagazine.com/region/east-africa/africas-largest-wind-farm-set-power-kenya/ (accessed 27 June 2018); WindPower (2016), '61MW Kinangop project cancelled', 25 February 2016:

http://www.windpowermonthly.com/article/1385206/61mw-kinangop-project-cancelled (accessed 27 June 2018).

${ }^{119}$ Reuters (2016), 'Kenyan wind power project cancelled due to land disputes', 23 February 2016: https://www.reuters.com/article/kenya-electricity/kenyan-wind-power-project-cancelled-due-to-land-disputes-idUSL8N1620QG (accessed 27 June 2018); WindPower (2016), '61MW Kinangop project cancelled', 25 February 2016: http://www.windpowermonthly.com/article/1385206/61mw-kinangop-project-cancelled (accessed 27 June 2018).

${ }^{120}$ Bloomberg (2018c), 'Actis to Buy 88\% Stake in 100-Megawatt Kenyan Wind Project', 23 May 2018: https://www.bloomberg.com/news/articles/2018-05-23/actis-plans-to-buy-88-stake-in-100-mw-kenyan-wind-power-project (accessed 27 June 2018).

${ }^{121}$ The Star (2018b), 'Land battles, tender wars and cost secrets: Did Kenya bite off too much with energy projects?' 2 June 2018: https://www.the-star.co.ke/news/2018/06/02/land-battles-tender-wars-and-cost-secrets-did-kenya-bite-off-toomuch c1766702 (accessed 27 June 2018)
} 

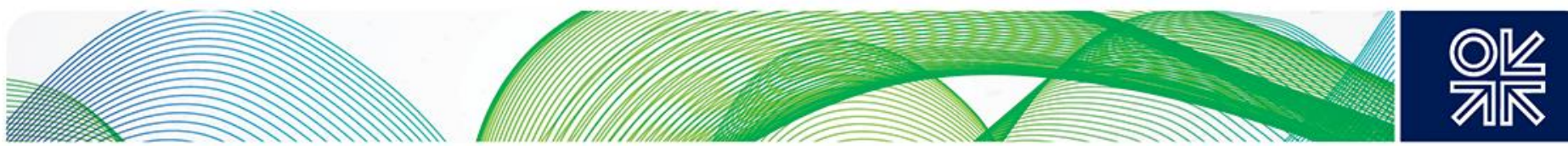

Tullow Oil's operations in Turkana, forcing the company to suspend operations for two weeks. ${ }^{122}$ Ethnic competition needs to be considered as part of local content policies. Investment projects seen to be benefiting (whether directly or indirectly) one local group to the disadvantage of another will face significant protest risks. Such risks extend to property damage, in the form of arson and vandalism, which in turn can result in suspension of operations.

Figure 8: Violent incidents in Kenya, January 2012-May 2018

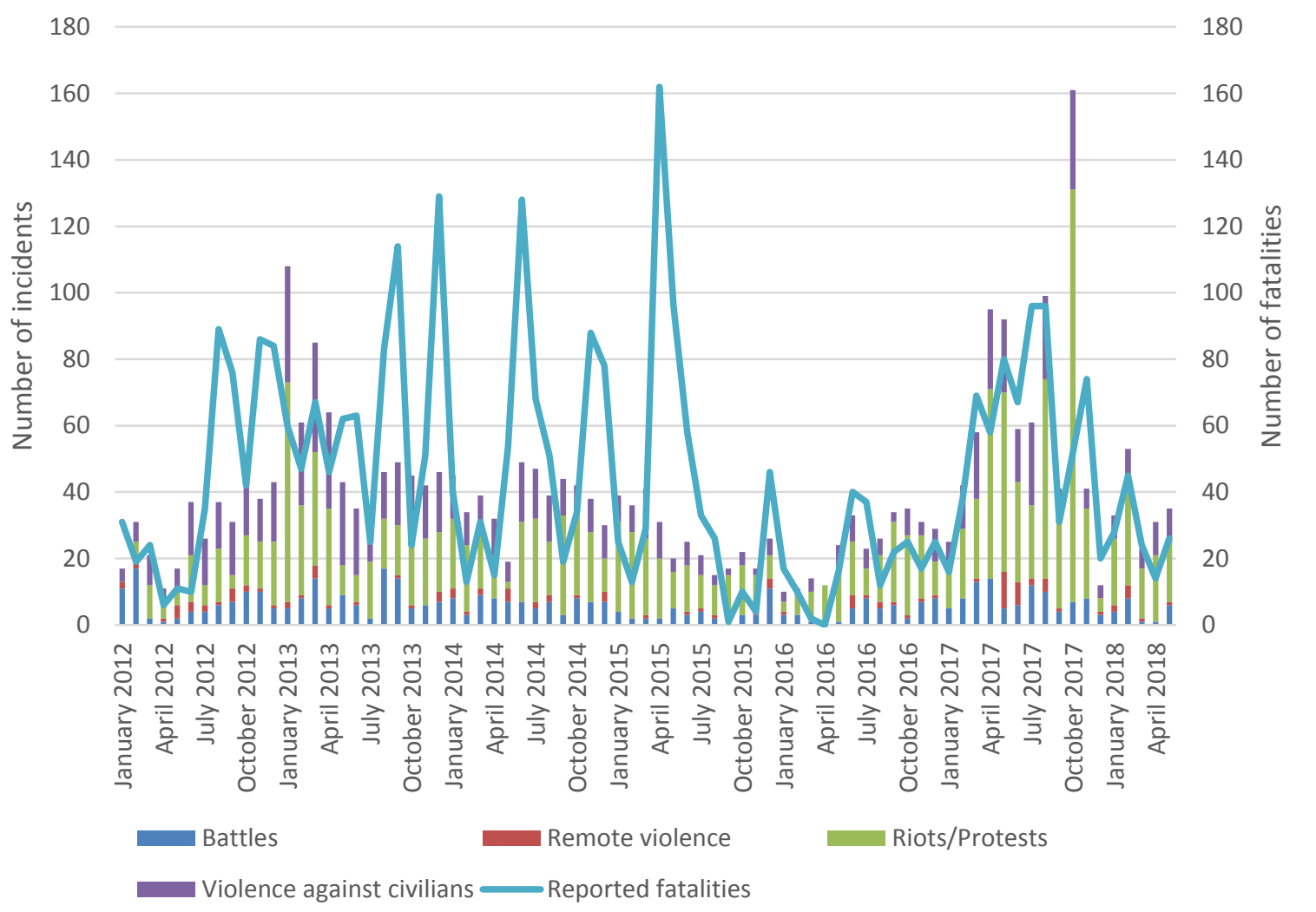

Source: ACLED (The Armed Conflict Location and Event Data Project), 2018.

Violent risks are lower for off-grid solutions where expectations over jobs and other benefits are limited. However, competition for service contracts is still likely to be fierce. Off-grid projects also face higher crime risk than large projects. Theft of solar panels and other equipment in rural areas is relatively frequent. ${ }^{123}$

\footnotetext{
${ }^{122}$ The protests were led by local MP James Lomenen, who demanded the company hire more locals. At the time, 800 of the 1,400 people employed on Tullow's Kenya operations were from Turkana county. Sources interviewed in 2013 claimed that Lomenen had stoked protests after a company he was affiliated with was passed over for a contract with Tullow. These claims are unsubstantiated, and denied by Lomenen. Regardless, Tullow increased the share of Turkanans within its workforce. Financial Times (2013), 'Tullow temporarily halts Kenya work after protests', 28 October 2013: https://www.ft.com/content/682ea95a-3fe1-11e3-a890-00144feabdc0 (accessed 27 June 2018).

${ }^{123}$ ESI Africa (2017), 'Kenya Power enhances security operation to mitigate theft and vandalism', 11 July 2017: https://www.esiafrica.com/kenya-power-enhances-security-operation-mitigate-theft-vandalism/ (accessed 27 June 2018).
} 

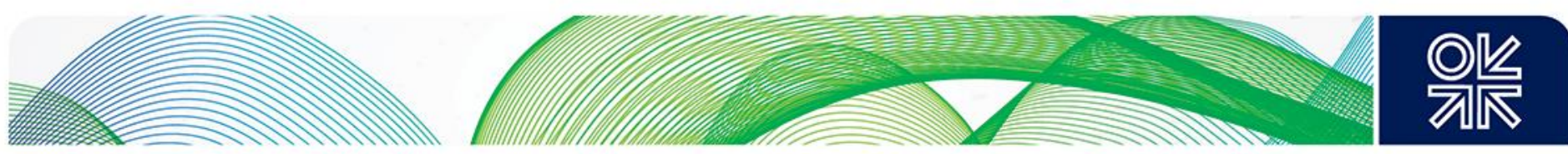

Over the last decade, investors in large physical assets have also expressed significant concerns over terrorism risks. ${ }^{124}$ Kenya has a history of high-profile terrorist attacks, including those on Westgate Shopping Mall in 2014 and Garissa University in 2015. There have also been numerous kidnappings of foreigners by either Islamist terrorists or Somali-based pirates, particularly in the north-eastern region. However, there is no evidence that Islamist groups in Kenya would have the intent to target large-scale economic projects. They have shown a preference for high casualty attacks on soft targets - the same tactics used most commonly in Somalia - and over the last two to three years they have not demonstrated the capability to stage complex attacks on well-guarded assets. Were capabilities and target preferences to change, renewable energy projects are not economically important enough to face a high risk. As with all sectors, Western staff involved in on- and off-grid projects will still face moderate risks of being caught up in violent protests or terrorism incidents in urban areas, notably Nairobi and Mombasa.

\subsection{Kenya summary}

Unlike Ethiopia, many of the major challenges in Kenya fall outside the regulatory environment, making them harder to control through government policy. The government has welcomed the private sector and built a relatively strong legislative and regulatory framework. Although there is some uncertainty due to the delayed Energy Bill 2017, the changes are likely to be positively received by investors.

These regulatory efforts are undermined by bureaucratic inefficiencies and high levels of corruption that are likely to affect a significant proportion of interactions with the government. Further, the level of tribalism within the political system means cyclic disruption associated with elections, and a complex social environment for investors to navigate. Land politics is a particularly high risk, with many largescale projects facing either protracted litigation or violent protests in connection to their physical assets.

Kenya's biggest strengths as an investment destination lie in off-grid and micro-grid solutions. These projects are less affected by the operating challenges outlined above. Contrary to Ethiopia, where the level of state control reduces scope for private sector growth, Kenya's welcoming environment has turned it into an innovation hub for these projects.

\section{Conclusion}

The renewable energy sector in East Africa presents a vibrant investment environment with opportunities for large on-grid projects in geothermal and wind, as well as commercially viable distributed solar investments. However, the prevalence of political, regulatory, and security risks can contribute to long delays in project finance. In some cases, investors have pulled out of projects or closed operations down entirely as a result of the regulatory uncertainty or physical threat to their assets. Yet despite this, an increasing number of private power producers persevere to reach financial close, and over the last year, off-grid ventures have completed record funding rounds.

East Africa is home to one of the largest hydropower projects in the world (the GERD, Ethiopia), one of the largest planned geothermal projects in Africa (Corbetti, Ethiopia), and the largest onshore wind

\footnotetext{
${ }^{124}$ There has been a militant Islamist presence in Kenya for decades, as demonstrated by the 1998 bombing of the US Embassy in Nairobi. However, for most of the early 2000s, there was relative calm. Attacks spiked again after the army's 2011 invasion of Somalia. The military engagement was authorized following a series of piracy-related kidnaps in the Lamu region.
} 

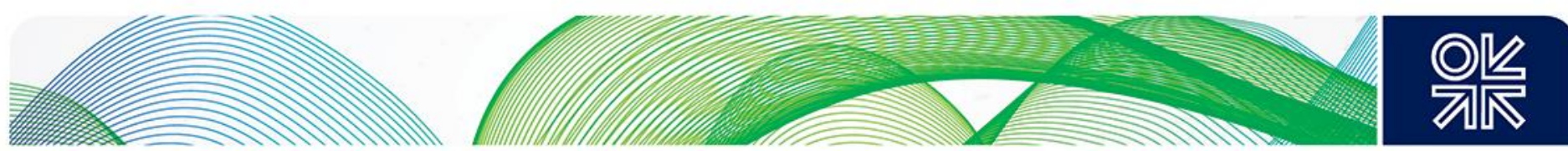

development in Africa (Lake Turkana, Kenya). Equally, two record-breaking off-grid ventures are also in the region: M-Kopa in Kenya and Off Grid Electric in Tanzania, amongst others.

These examples hint to one of the key findings of this paper: that Ethiopia looks more favourably on large utility-scale projects, and that Kenya presents opportunities in off-grid innovation. This is partly driven by the differing risk landscapes in these countries. In Ethiopia, the risk is primarily in the political and regulatory stage, whereas physical asset risks are lower. The country's less developed regulatory system means that investors are likely to be more reliant on government support to push ahead with a project. The government has proven more willing to throw its weight behind large utility-scale investments, while gaps in the legislation still prevent the rapid expansion of private off-grid investment.

Meanwhile in Kenya, asset risks are significantly higher and regulatory gaps are fewer. This creates an environment where projects with a large physical presence are at a disadvantage. Problems with land access and a high risk of protests can cause major delays to large, on-grid projects, but pose little or no risk to distributed off-grid models. Equally, since the legislative and regulatory environment is more developed, it includes provisions covering off-grid and micro-grid systems. This, combined with the boom in mobile payment technologies, has allowed for the roll-out of pay-as-you-go solar systems that support government electrification targets while still providing returns to international investors.

An understanding of these complex policy environments is not a panacea, and many projects in the region will still require extra due diligence before securing financing, including investigation into issues such as counter-party risk. However, the renewable energy sector is evolving rapidly, and both Ethiopia and Kenya have demonstrated their potential to be booming markets for the right investors. 